\title{
Peatlands and the carbon cycle: from local processes to global implications - a synthesis
}

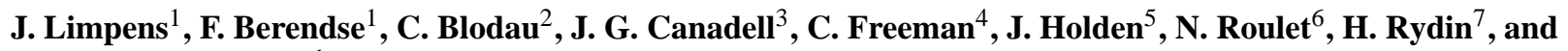 \\ G. Schaepman-Strub ${ }^{1}$ \\ ${ }^{1}$ Nature Conservation and Plant Ecology Group, Wageningen University, Wageningen, The Netherlands \\ ${ }^{2}$ Limnological Research Station and Department of Hydrology, University of Bayreuth, 95440 Bayreuth, Germany \\ ${ }^{3}$ Global Carbon Project, CSIRO Marine and Atmospheric Research, GPO Box 3023, Canberra, ACT 2601, Australia \\ ${ }^{4}$ School of Biological Sciences, Bangor University, Wales, LL57 2UW, UK \\ ${ }^{5}$ School of Geography, University of Leeds, Leeds, LS2 9JT, UK \\ ${ }^{6}$ Department of Geography, McGill University, 805, Sherbrooke Street West, Montréal, Québec, H3A 2K6, Canada \\ ${ }^{7}$ Department of Plant Ecology, Evolutionary Biology Centre, Uppsala University, Villavägen 14, 75236 Uppsala, Sweden
}

Received: 12 February 2008 - Published in Biogeosciences Discuss.: 4 April 2008

Revised: 3 September 2008 - Accepted: 17 September 2008 - Published: 31 October 2008

\begin{abstract}
Peatlands cover only 3\% of the Earth's land surface but boreal and subarctic peatlands store about $15-30 \%$ of the world's soil carbon (C) as peat. Despite their potential for large positive feedbacks to the climate system through sequestration and emission of greenhouse gases, peatlands are not explicitly included in global climate models and therefore in predictions of future climate change. In April 2007 a symposium was held in Wageningen, the Netherlands, to advance our understanding of peatland $\mathrm{C}$ cycling. This paper synthesizes the main findings of the symposium, focusing on (i) small-scale processes, (ii) $\mathrm{C}$ fluxes at the landscape scale, and (iii) peatlands in the context of climate change.

The main drivers controlling $C$ fluxes are largely scale dependent and most are related to some aspects of hydrology. Despite high spatial and annual variability in Net Ecosystem Exchange (NEE), the differences in cumulative annual NEE are more a function of broad scale geographic location and physical setting than internal factors, suggesting the existence of strong feedbacks. In contrast, trace gas emissions seem mainly controlled by local factors.

Key uncertainties remain concerning the existence of perturbation thresholds, the relative strengths of the $\mathrm{CO}_{2}$ and $\mathrm{CH}_{4}$ feedback, the links among peatland surface climate, hydrology, ecosystem structure and function, and trace gas biogeochemistry as well as the similarity of process rates across peatland types and climatic zones. Progress on these research areas can only be realized by stronger co-operation between disciplines that address different spatial and temporal scales.
\end{abstract}

Correspondence to: J. Limpens (juul.Limpens@wur.nl)

\section{Introduction}

Peatlands are wetlands with an organic soil layer of at least $30 \mathrm{~cm}$, which may extend to $15-20 \mathrm{~m}$ depth with an estimated mean between 1.3-2.3 $\mathrm{m}$ for northern peatlands (Clymo et al., 1998; Turunen et al., 2002). Peatlands cover about 4.16 $\times 10^{6} \mathrm{~km}^{2}$ worldwide, with $80 \%$ of the peatland area situated in temperate-cold climates in the northern hemisphere, particularly in Russia, Canada and the USA. The remaining peatlands are found in tropical-subtropical climates, particularly in south-east Asia (Joosten, 2004, Global Peatland Database).

Despite covering less than 3\% of the Earth's land surface, boreal and subarctic peatlands store between 270 and $370 \mathrm{Tg} \mathrm{C}\left(1 \mathrm{Tg}=10^{12} \mathrm{~g}\right)$ as peat (Turunen et al., 2002), which would amount to $34-46 \%$ of the $796 \mathrm{Tg} \mathrm{C}$ currently held in the atmosphere as $\mathrm{CO}_{2}$ (IPCC 2007). Tropical peatland $\mathrm{C}$ stores are estimated to be around $52 \mathrm{TgC}$, with very large uncertainties (8-258 Tg C, Hooijer et al., 2006). These massive deposits are the legacy of peatlands acting as sinks of atmospheric carbon dioxide $\left(\mathrm{CO}_{2}\right)$ for millennia; but they also illustrate the potential for large $\mathrm{CO}_{2}$ and methane $\left(\mathrm{CH}_{4}\right)$ fluxes to the atmosphere or dissolved carbon (DC) to rivers if peatland $\mathrm{C}$ stores were to be destabilized by global warming and changes in land use. Up to now, peatlands have contributed to global cooling on the millennium scale (Frolking and Roulet, 2007) and, undisturbed peatlands are likely to continue functioning as net $\mathrm{C}$ sinks despite the large interannual variability of individual peatlands (Moore et al., 1998). Whether peatlands will continue their function as net $\mathrm{C}$ sinks in the long term remains uncertain, and depends on the impact of environmental and anthropogenic forcing on

Published by Copernicus Publications on behalf of the European Geosciences Union. 
the $\mathrm{C}$ balance of these ecosystems (Moore, 2002; Page et al., 2002). Despite their proven role in past and present global cooling and their potential for large positive feedbacks to the climate system through sequestration and emission of greenhouse gases, peatlands are not explicitly included in global climate models and therefore in predictions of future climate change (IPCC, 2007).

In April 2007 a symposium was held in Wageningen, the Netherlands (Wieder et al., 2007), to advance our understanding of peatland $\mathrm{C}$ cycling through integration across disciplines and research approaches, and to develop a more synthetic picture of the present and future role of peatlands in the global $\mathrm{C}$ cycle and their interactions with the climate system. This paper aims to synthesize the main findings of the symposium.

With a process based approach we hope to contribute to the integration of research results across peatland types and climatic zones, improving future predictions of the response of the peatland $\mathrm{C}$ balance to environmental and climate change. This paper presents a new synthesis on (i) small-scale processes, (ii) $\mathrm{C}$ fluxes at the landscape scale, and (iii) peatlands in the context of climate change. The paper concludes with directions for new research to reduce key uncertainties in our knowledge in order to facilitate the explicit inclusion of these ecosystems in a new generation of earth system models.

\subsection{Generalisations accross peatland types}

The necessity of focusing on processes becomes clear when we consider the large variation in peatland types. Peatlands comprise many different ecosystems (Rydin and Jeglum, 2006) with and without a tree and/or moss layer. Fortunately, there are some unifying concepts that apply across different peatland types although Sphagnum-dominated peatlands are the most studied compared to other peatland types. The redox potential is decisive for many biogeochemical processes in the peat, and this is largely governed by the position of the water table. The upper peat layer (about $5-40 \mathrm{~cm}$ ) is unsaturated with water and oxic during the growing season and supports most biological activity, whereas the layer below is waterlogged and anoxic. The oxic-anoxic boundary shifts as a result of water table fluctuations. Another key distinction is made on the dominant water source influencing the organic soil layer. Peatlands that receive most of their water from precipitation are referred to as ombrotrophic peatlands or bogs, whereas peatlands that are mainly fed by water that has been into contact with the mineral soil are referred to as minerotrophic peatlands or fens.

\section{Small scale processes and plant-soil feedbacks}

Understanding the mechanisms controlling aerobic and anaerobic respiration at small spatial scales is particularly important for improving our predictions of potential effects of climate changes and perturbations on peatland $\mathrm{C}$ flux. An example of a key process is nitrogen $(\mathrm{N})$ fertilization due to anthropogenic-driven $\mathrm{N}$ deposition. Feedbacks between vegetation, soil physical processes and aerobic and anaerobic respiration will further help understanding the high spatial and temporal variability of peatland $\mathrm{C}$ fluxes to waterways and the atmosphere, in particular the production and oxidation of $\mathrm{CH}_{4}$ (Sects. 3 and 4) and generation and export of dissolved organic carbon (DOC, Sects. 3 and 4).

\subsection{Biogeochemistry}

The decomposition of complex organic matter to final products, i.e. $\mathrm{CO}_{2}, \mathrm{CH}_{4}$ and DOC, is the result of a close interaction of microorganism activity, physically controlled transport processes of electron acceptors and nutrients, and the quality of the organic matter itself. I addition, the decomposition process is regulated by the availability and efficiency of extracellular enzymes, which break down complex biomolecules into monomers that can be utilized by microorganisms. Changes in the environment can either directly affect microbial activity by acting on the availability of nutrients and electron acceptors or indirectly through changes in vegetation or soil physical structure. Direct impacts are, for example, caused by the deposition of $\mathrm{N}$ and sulphur (S), or oxygenation after water table draw-down during summer drought. Indirect impacts comprise the change towards plant species with more decomposable litter or more root exudates (see Sect. 2.2).

\subsubsection{Biogeochemical processes and drivers}

Below-ground C cycling, irrespective of peatland type, can be conceptualized in terms of electron transfer processes (Fig. 1a). Primary production provides reduced compounds that are buried as litter or released below-ground by vascular roots, creating a redox gradient to the atmosphere. This gradient results in $\mathrm{O}_{2}$ transfer by gas diffusion, advection and aerenchymatic transport in roots and also influences belowground oxygen $\left(\mathrm{O}_{2}\right)$ consumption itself (Shannon and White, 1994; Chanton and Whiting, 1996). Oxidative capacity can further be stored in the form of nitrate, ferric iron hydroxides, sulfate $\left(\mathrm{SO}_{4}\right)$, and humic substances that can be used as alternatives for $\mathrm{O}_{2}$ in heterotrophic respiration. Which oxidant is used by the resident microbial community is broadly regulated by differences in the Gibbs free energy of the respective respiration processes (Fig. 1d) and the concentrations of electron acceptors and donors (Achtnich et al., 1995; Keller and Bridgham, 2007).

In peatlands, electron transfer processes proceed in a strongly vertically structured environment, which is illustrated in Fig. 1b. From the peat surface downwards four main characteristics change: (1) the relative importance of root respiration versus heterotrophic respiration decreases with depth. Fine roots of shrubs, for example, are largely 
Processes

(a)

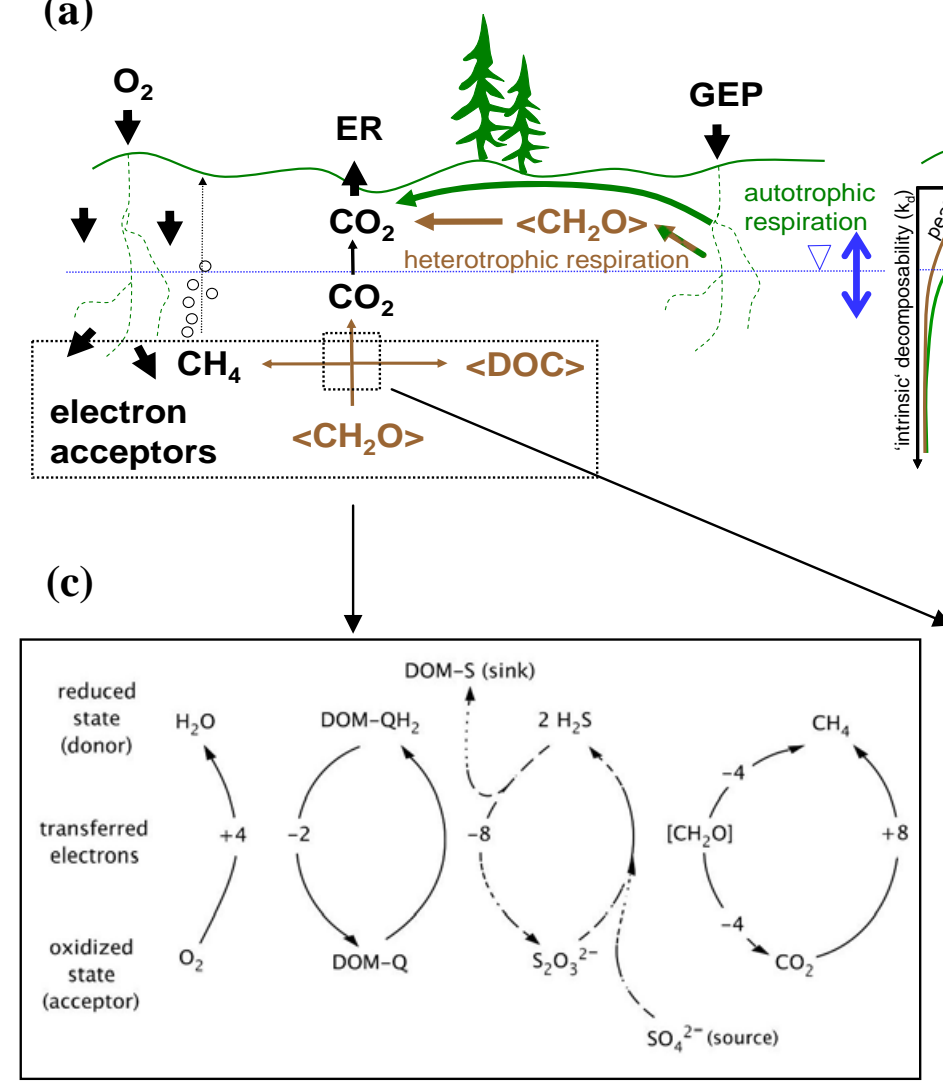

(b)

\section{Controls}

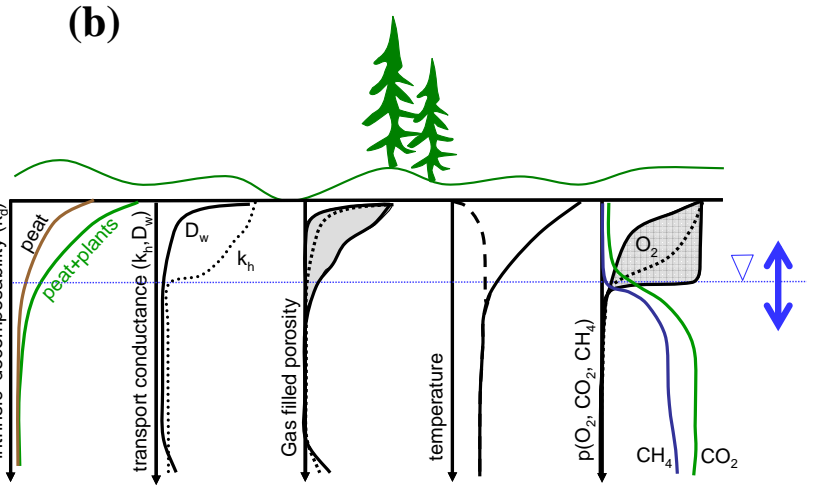

(d)

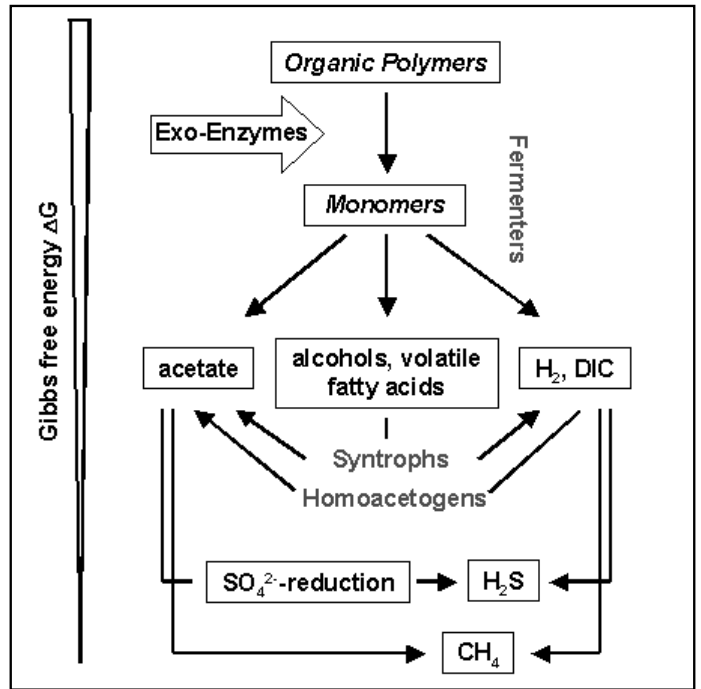

Fig. 1. Schematic of (A) small-scale biogeochemical processes, (B) distribution of controls involved in belowground carbon cycling in peatlands, (C) recharging of electron acceptors, redox potential declines from left to right, (D) the regulation and impact of exo-enzymatic activity on decomposition. Abbreviations not explained in text: $\mathrm{ER}=$ Ecosystem Respiration, $\mathrm{GEP}=\mathrm{Gross}$ Ecosystem Production, $\mathrm{CH}_{2} \mathrm{O}$ $=$ organic matter, $k_{d}=$ decomposition, $k_{h}=$ hydraulic conductivity, $D_{w}=$ Diffusion). Most uncertainties lie in the process rates and spatiotemporal variability of the controls.

restricted to the upper zone, which is at least intermittently unsaturated and oxic (Moore et al., 2002); (2) Litter degradability also decreases with depth, as the ongoing decomposition produces increasingly decomposed and recalcitrant litter residues. This is not a uniform process, however, as litter input also occurs further down in the form of dead roots, root exudates and litter leachates (Chanton et al., 1995); (3) The transport of gases and solutes slows with depth, because diffusion coefficients and hydraulic conductivities of the peat decrease with water saturation and compaction (Waddington and Roulet, 1997; Fraser et al., 2001); and (4) the concentrations of electron acceptors, in particular oxygen, de- crease with distance from their atmospheric source and deplete rapidly in the saturated zone below the water table (Blodau et al., 2004). The transition between unsaturated and saturated zone seems particularly sharp after long periods without rain (Hornibrook et al., 2008).

The oxidation processes that follow the water table draw down and lead to the recharge of electron acceptor pools have not been well investigated. This limits the ability to assess the impact of drought-rewetting cycles on subsequent $\mathrm{CO}_{2}$ and $\mathrm{CH}_{4}$ production. Generally, the recharging (i.e. oxygenation) of a particular electron acceptor is possible by oxygen transfer into the saturated zone by root conduit transport, 
mixing by precipitation, water movement, water table fluctuations, and by the utilization of reservoirs of other electron acceptors with a more positive redox potential (Fig. 1c). For example, the electron acceptors contained in humified organic matter may also allow for the chemical oxidation of hydrogen sulfide $\left(\mathrm{H}_{2} \mathrm{~S}\right)$ and thus maintain anaerobic $\mathrm{S}$ cycling and $\mathrm{CO}_{2}$ production (Heitmann and Blodau, 2007).

\subsection{2 $\mathrm{CH}_{4}$ emission}

The emission of $\mathrm{CH}_{4}$ is a function of its rate of production, transport and oxidation. High peat decomposition rates in warm and poorly decomposed peat, local anoxia, provision of substrates by roots, and rapid transport to the surface by ebullition and through conduits, such as vascular plant roots or stems, generally lead to high $\mathrm{CH}_{4}$ emissions (Shannon and White, 1994; Fechner-Levy and Hemond, 1996; Coles and Yavitt, 2004). The coupling between C, N, Fe, and S transformations is also important. Iron and $\mathrm{SO}_{4}$ reducing bacteria can suppress $\mathrm{CH}_{4}$ production even at low concentrations of these alternative electron acceptors (Kristjansson et al., 1982; Achtnich et al., 1995). The potential effect of S deposition on $\mathrm{CH}_{4}$ emission from nutrient-poor peatlands has been identified by studies across $\mathrm{S}$ deposition gradients in eastern North America and Europe (Nedwell and Watson, 1995; Gauci et al., 2002; Vile et al., 2003). The authors showed that $\mathrm{CH}_{4}$ production rates increased and $\mathrm{SO}_{4}$ reduction rates decreased with increasing $\mathrm{S}$ deposition. Future exploitation and combustion of oil sands and coal reserves will thus likely lead to increases in $\mathrm{S}$ deposition and continued depression of $\mathrm{CH}_{4}$ emission from peatlands

\subsubsection{Novel controls on biogeochemical processes}

Organic matter decomposition and methanogenesis are potentially influenced by the effects of extracellular enzyme activity and by the accumulation of decomposition products due to the slowness of transport processes in water saturated peat. As was outlined above, the electron transfer processes that finally lead to, or influence, $\mathrm{CO}_{2}, \mathrm{CH}_{4}$ and DOC fluxes are almost exclusively microbially mediated and require the exo-enzymatic cleavage of complex litter and soil organic matter molecules (Conrad, 1999; Fig. 1d). The role of phenol oxidase enzymes is particularly important in this process and the cycling of phenolic compounds that may interfere with other extracellular enzymes (Benoit and Starkey, 1968; Albers et al., 2004). Phenol oxidase enzymes are oxidative copper-containing enzymes that catalyse the release of reactive oxygen-radicals (Hammel, 1997; Claus, 2004) and are produced by a wide range of micro-organisms such as fungi (Hammel, 1997; Burke and Cairney, 2002), bacteria (Hullo et al., 2001; Fenner et al., 2005) and actinomycetes (Crawford, 1978; Endo et al., 2003). Changes in the activity of extracellular phenol oxidases may affect the retention of $\mathrm{C}$ in the soil environment directly via the breakdown of otherwise highly recalcitrant organic matter and indirectly by releasing extracellular hydrolase enzymes from phenolic inhibition (Pind et al., 1994; Freeman et al., 2001a, 2004); consequently playing an important role in the stability of peatland $\mathrm{C}$ stores. The activity of extracellular phenol oxidases is constrained by low oxygen availability (McLatchey and Reddy, 1998), low temperatures (Freeman et al., 2001b) and low pH (Criquet et al., 1999). Such conditions are characteristic of northern peatlands, and the release of phenol oxidase activity from one or a combination of these inhibitory factors can therefore release an "enzymic latch mechanism" (Freeman et al., 2001a) allowing destabilization of peatland $\mathrm{C}$ storage.

Recent studies also suggest that the impact of water saturation, anaerobia and associated accumulation of decomposition products may be larger than derived from laboratory incubations, and can result in a near shut down of hetero- and autotrophic respiration deeper into the saturated zone of ombrotrophic peat soils (Beer and Blodau, 2007; Blodau et al., 2007). If such findings could be generalized, $C$ fluxes from heterotrophic respiration could be modeled by the depth of the unsaturated layer, the distribution of the decomposition constant, the soil temperature, and the photosynthetically driven root exudation rate in the unsaturated zone. Such an approach is to some extent limited in situations when water contents become very high, i.e. in the capillary fringe of peat soils. In this zone oxygen transport is impeded, likely leading to spatiotemporally variable mosaic of oxic and anoxic microenvironments with variable respiration rates and pathways (Knorr et al., 2008).

Currently our knowledge about the soil physical properties that control biogeochemical processes in the capillary fringe is limited, and even less is known about its variability within and among different peatland types. When saturation approaches $100 \%$, it is likely that even small changes in water content can have large impacts on rates of heterotrophic respiration, methane production and oxidation, as well as on other redox processes. Assessments about the impacts of intensified drought and rewetting on below ground carbon cycling will thus depend on a better understanding of the interaction between soil physical properties, transport and biogeochemical processes. The relationship between hydrology and respiration processes seems somewhat simpler in the saturated zone where heterotrophic respiration relies on the influx of oxygen as well and, apparently, also on the removal of organic matter decomposition products. Transport is slow in diffusion dominated systems and fast when advection of soil water predominates, leading to short residence times of water in the soils. To link respiration to peatland hydrology and climate change, the water residence time, or the time that a certain volume of soil is occupied by the same body of water, may thus offer a promising concept. 


\subsection{Vegetation-mediated feedbacks}

At an ecosystem scale, water level and $\mathrm{pH}$ control the vegetation composition. In turn the vegetation composition affects the $\mathrm{C}$ balance through its effects on net primary productivity (NPP), the amount and ratio of $\mathrm{CO}_{2}: \mathrm{CH}_{4}$ released into the atmosphere and peat physical properties (Fig. 5). As plants and vegetation types generally form easily recognizable units for both land-based and airborne assessments and are closely coupled to soil processes, vegetation changes are both convenient predictors for environmental changes to come as well as monitoring tools for changes underway.

Plants differ in important characteristics such as productivity, litter decomposability and association with fungi which in turn affects the $\mathrm{C}$ balance of peatlands at local to ecosystem scales. This results in a number of vegetationbiogeochemistry feedbacks: (1) There is a general trade-off between hummock and hollow inhabiting Sphagnum species, with lower decomposability among the former, and higher productivity among the latter (Rydin et al., 2006); (2) Ombrotrophic growing Sphagnum species are usually difficult to decompose compared with most co-inhabiting vascular plants (Limpens and Berendse, 2003; Dorrepaal et al., 2005); (3) The decrease in litter $\mathrm{C}: \mathrm{N}$ ratio following from $\mathrm{N}$ deposition may enhance decomposition (Limpens and Berendse, 2003; Bragazza et al., 2006); (4) Plants produce peat with different structure and hydraulic conductivity, features that in turn affect redox status and other physico-chemical conditions. For instance, for the same degree of humification, the hydraulic conductivity generally increases in the order Sphagnum peat < Carex peat < woody peat (Päivänen, 1982); (5) Plant differ in the rate and degradability of their (root) exudates (Crow and Wieder, 2005); and (6) An increasing sedge or graminoid cover will increase $\mathrm{CH}_{4}$ emission through aerenchymatic tissue (Thomas et al., 1996; Nilsson et al., 2001).

On the whole, the vegetation that dominates a peatland will not only affect photosynthetic and respiration rates, but also the amount of $\mathrm{C}$ available for mobilisation as DOC from the peatland. For example, vegetation types in Alaska may be more important than regional climate in determining DOC fluxes from peatlands (Neff and Hooper, 2002). Figure 2 presents results from a survey across UK blanket peats showing that DOC concentrations are significantly greater where woody Calluna dominates when compared to Eriophorumdominated sites or Sphagnum-Eriophorum sites.

Finally, large-scale changes in shrub and tree cover, going from tundra to taiga (Chapin et al., 2005) or from taiga to bog (Vygodskaya et al., 2007), involves marked changes in albedo, in turn affecting the amount of solar energy absorbed by the soil, with important potential feedbacks to permafrost depth and local water table.

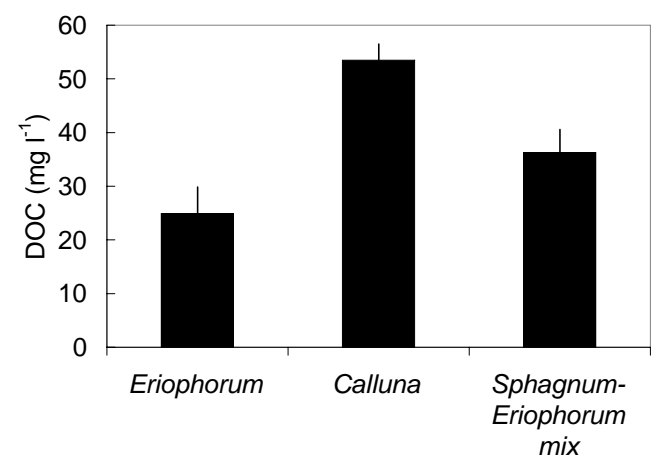

Fig. 2. DOC concentrations in stream water from UK blanket peatland catchments (mean \pm SE) dominated by particular vegetation types. No burning occurred on the catchments used to derive data in the figure. Collection of the data was performed by Dr. Alona Armstrong and was funded by Yorkshire Water.

\subsubsection{Vegetation responses to environmental change}

Apart from the obvious destruction of peatlands by drainage, climatic changes that affect water availability are, together with $\mathrm{N}$ deposition, the most important factors altering peatland vegetation in temperate and boreal regions. There is quite a good understanding from ecological experiments how different peatland plant species react to water table position, wetness (Rydin and Jeglum, 2006) and N deposition (Limpens et al., 2006). Precipitation frequency during the growing season is a particularly important factor in controlling Sphagnum photosynthesis (Robroek et al., 2008), which constitutes an important part of the NPP in many peatlands. In general, decreasing wetness during the growing season as well as increases in $\mathrm{N}$ deposition stimulate vascular plant growth at the cost of Sphagnum, with the magnitude of effects greatly depending on the starting conditions. The shift from a Sphagnum dominated to vascular plant dominated vegetation type coincides with increases in litter decomposability (Dorrepaal et al., 2005), heterotrophic respiration (Bubier et al., 2007), hydrological conductivity of the upper peat layer (Belyea and Baird, 2006) and a general decline of $\mathrm{C}$ sequestration in the longer term. The future challenge is to understand how various climate scenarios affect the wetness of the peatlands, and how this in turn leads to vegetation changes through differential growth and interspecific competition. How the latter is affected by different $\mathrm{N}$ deposition loads is particularly of interest in areas with $\mathrm{N}$ deposition increasing above c. $1-1.5 \mathrm{~g} \mathrm{~m}^{-2} \mathrm{yr}^{-1}$. This research field, requiring dynamic vegetation models that allow for continuous feedbacks between vegetation and environment, is just starting to emerge (Heijmans et al., 2008; St-Hilaire et al., 2008).

$\mathrm{N}$ deposition above c. $1-1.5 \mathrm{~g} \mathrm{~m}^{-2} \mathrm{yr}^{-1}$ generally increases vascular plant cover, and decreases Sphagnum cover, although changes may be slow, and experimentally difficult 
to demonstrate, especially in regions with low background deposition where the Sphagnum layer is not yet N saturated. Whereas vegetation changes were reported within 4 years of $\mathrm{N}$ fertilization at high background deposition in the Netherlands (Limpens et al., 2004), it took 5-8 years for the first effects to emerge in Northern Sweden and Canada (Bubier et al., 2007; Wiedermann et al., 2007). An increase in cover of vascular plants beyond a critical limit inevitably leads to a decrease in Sphagnum cover (Berendse et al., 2001), and this alteration in dominance of the different groups of plants is driven by positive feedbacks mediated by increased light competition and decreased uptake of N by the Sphagnum mosses (Limpens et al., 2006; Rydin and Jeglum, 2006). Long-term monitoring has shown that $\mathrm{N}$ demanding species have increased on ombrotrophic peatlands in SW Sweden over the last decades (Gunnarsson and Flodin, 2007).

Increased temperature probably affects vegetation more by indirect effects such as increased evaporation and reduced snow cover than by direct, differential effects on plant species performance (Weltzin et al., 2001). Experiments show that temperature effects on Sphagnum growth are species-dependant (Robroek et al., 2007) and can interact with $\mathrm{N}$ deposition (Weidermann et al., 2007). However, it is unclear if this eventually may shift the species balance to such extent that $\mathrm{C}$ cycling is significantly affected.

While increased concentrations of $\mathrm{CO}_{2}$ in the air may affect the physiology and growth of plants (Jauhiainen et al., 1998), most studies have failed to demonstrate strong effects on peatland species composition (Berendse et al., 2001; Heijmans et al., 2002). In contrast, Fenner et al. (2007a) showed increased vascular plant cover at the expense of Sphagnum in minerotrophic peatland vegetation subjected to elevated $\mathrm{CO}_{2}$. Increased $\mathrm{C}$ turnover in vascular plants, particularly Juncus effusus, resulted in higher DOC concentrations via exudation and accelerated decomposition of litter and peat. Moreover, a more than additive effect was found due to the interaction between $\mathrm{CO}_{2}$ and warming, leading to even greater increases in vascular plant dominance, decomposition and DOC release (Fenner et al., 2007b).

A field experiment in Switzerland showed a differential effect on $\mathrm{N}$ and $\mathrm{CO}_{2}$ on the growth of peatland bryophytes (Mitchell et al., 2002): height growth of Polytrichum strictum was favored by $\mathrm{N}$ addition, whereas Sphagnum fallax was favored by increased $\mathrm{CO}_{2}$ concentration. Such contrasting effects on height growth may be more important than effects on biomass accumulation for competition and changes in species composition, since competitive outcome in bryophytes to a large extent is determined by overtopping and shading effects (Rydin, 2009). The results indicate that even for such a 'N-tolerant' species as $S$. fallax, the negative effects of $\mathrm{N}$ deposition are more important than any positive $\mathrm{CO}_{2}$ effects.

There is very little data about the natural changes in peatland vegetation as a result of climate variability. In the absence of human impact the species composition of temper- ate and boreal ombrotrophic peatlands (bogs) appears to be very stable. This holds for fine-scale (less than $1 \mathrm{~m}$ ) persistence of Sphagnum species over centuries-millennia (Rydin and Barber, 2001), and also for stability of microtopographic structure (hummock-hollow patterns over 40-60 yr (Backéus, 1972; Rydin et al., 2006). However, recent reanalyses of bogs that were studied in detail in the 1940s and 1950s reveal larger changes. In a peatland in central Sweden with low levels of air pollution there were clear indications of acidification and associated changes in bryophyte composition (Gunnarsson et al., 2000, 2002). Novel approaches based on remote sensing data, such as mapping the leaf area index of trees and shrubs (Sonnentag et al., 2007) or the plant functional type fractional cover in peatlands (SchaepmanStrub et al., 2008) allow a spatially continuous assessment of the current status and the detection of changes in ecosystem functioning and vegetation composition.

\section{C fluxes at the landscape scale}

\subsection{Land-aquatic C fluxes}

The aquatic export from temperate and boreal peatlands ranges between 1 and $50 \mathrm{~g} \mathrm{DOC} \mathrm{m}^{-2} \mathrm{yr}^{-1}$ (Dillon and Molot, 1997), which typically represents around $10 \%$ of the total $C$ release, and is currently showing widespread increases (Freeman et al., 2001b; Worrall et al., 2003). For some mires, $\mathrm{CO}_{2}$ outgassing from the streams may comprise additional losses of 2 to $13 \mathrm{~g} \mathrm{C} \mathrm{m}^{-2} \mathrm{yr}^{-1}$ (Buffam et al., 2007). In the most severely eroding peat catchments in the UK, particulate organic carbon (POC) losses may exceed $100 \mathrm{~g} \mathrm{C} \mathrm{m}^{-2} \mathrm{yr}^{-1}$ (Evans and Warburton, 2007)

Wherever peatlands appear in the landscape they will dominate the fluvial fluxes of $\mathrm{C}$ in inorganic (DIC), DOC or POC form. Given the periodic nature of stream response (Bay, 1969; Price, 1992; Holden and Burt, 2003a) most of the aquatic $\mathrm{C}$ losses from peatlands occur during relatively short periods (during high flow), for example following heavy rain or snow melt. The dominant pathways for water movement in most ombrotrophic peatlands are near surface flow through the upper peat layers and saturation-excess overland flow (Holden and Burt, 2003a); matrix flow in deeper peat layers is severely limited (Rycroft et al., 1975; Holden and Burt, 2003b). However, large preferential pathways can exist in peatlands forming conduits (called macropores or pipes, depending on diameter, Fig. 3) for water and $\mathrm{C}$ that bypass near-surface and matrix flow. The occurrence of pipes is not related to slope gradient, although some topographic variation in the subsoil is necessary. Pipes have been reported for subarctic continental peats (Gibson et al., 1993; Carey and Woo, 2000), southern hemisphere patterned mires (Rapson et al., 2006) and some tropical peatlands (Buytaert et al., 2006). The effect of macropores and pipes on water and $\mathrm{C}$ flow can be substantial. Baird (1997) and Holden et al. (2001) showed 


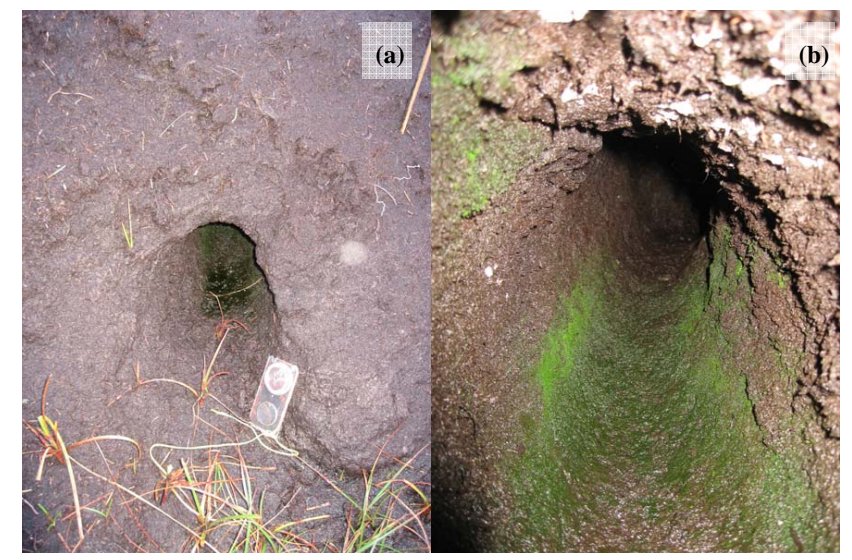

Fig. 3. A natural peatland pipe showing (A) the outlet on a stream bank (with compass for scale) and (B) the internal features of the pipe channel which is $27 \mathrm{~cm}$ tall.

that over 30\% of runoff in fens and blanket peats in the UK moves through macropores, resulting in water and nutrients being transferred between deep and shallow layers of the peat profile. There is even a theory that pipes can explain some of the additional degassing from bog pools that does not seem to be accounted for by bog pool size alone. Many drained peat pools have been found to have a natural peat pipe on their floor or wall (Rapson et al., 2006).

What is often ignored on a landscape scale is the variability in water table and runoff that can occur wherever peatlands are subject to any significant topographic variation. Underestimated is also the speed with which the dominant overland and near-surface flow in many peatlands may accelerate peat exposure after degradation of the vegetation cover, resulting in enhanced POC efflux and reduced NPP as a result of vegetation loss (Holden et al., 2007a).

\subsubsection{DOC fluxes}

DOC is important in peatlands because any change in the flux of DOC will result in a significant regional redistribution of terrestrial C. In downstream ecosystems, DOC exerts significant control over productivity, biogeochemical cycles and attenuation of visible and UV radiation (Pastor et al., 2003). In addition, DOC impacts water quality in terms of color, taste, safety, and aesthetic value, as well as altering the acid-base and metal complexation characteristics of soil water and stream water. Together with the $\mathrm{C}$ losses considerable nutrient export may occur as well, potentially increasing impacts on aquatic diversity downstream (Waldron et al., 2008). DOC accumulates in peat pore waters and is flushed out by water movement, with concentrations often greatest following periods of warm, dry conditions when DOC has had time to accumulate. DOC concentrations are usually between 20 and $60 \mathrm{mg}^{-1}$ in northern peatlands (Blodau, 2002) but concentrations are higher during low flow periods. Despite this the total flux of DC (DC = DOC + DIC) exported is likely to be higher during storm flows but many sampling programmes do not take this into account (Schiff et al., 1998). Recent strong interest in water-borne $\mathrm{C}$ exports from peatlands has focused mainly on concentrations and fluxes of $\mathrm{C}$, especially DOC within the drainage system of peat dominated catchments (Dawson et al., 2002; Billett et al., 2006). Buffam et al. (2007) reported DOC export for 15 Swedish peatland streams at $2-10 \mathrm{~g} \mathrm{C} \mathrm{m}^{-2} \mathrm{yr}^{-1}$ while DIC was between 0.2 and $2 \mathrm{~g} \mathrm{C} \mathrm{m}^{-2} \mathrm{yr}^{-1}$. However, we still know little about what controls the transport of DOC and particulate $\mathrm{C}$ release within peatlands themselves and the hydrological processes leading to their delivery to rivers.

\subsection{Land-atmosphere $\mathrm{C}$ fluxes}

The mass exchange of $\mathrm{C}$ between peatlands and the atmosphere is dominated by the fluxes of $\mathrm{CO}_{2}$ and $\mathrm{CH}_{4}$, but because of the different radiative properties of $\mathrm{CO}_{2}$ and $\mathrm{CH}_{4}$ the much smaller mass exchange of $\mathrm{CH}_{4}$ can have a disproportional effect on climate forcing.

\subsubsection{Net Ecosystem Exchange of $\mathrm{CO}_{2}$ (NEE)}

NEE from bogs, as determined by eddy co-variance systems, ranges from a net loss of $>100 \mathrm{~g} \mathrm{C} \mathrm{m}^{-2} \mathrm{yr}^{-1}$ for a permafrost dominated Siberian bog (Friborg et al., 2003) and Russian European boreal bogs (Arneth et al., 2002) to large uptakes of about $90 \mathrm{~g} \mathrm{C} \mathrm{m}^{-2} \mathrm{yr}^{-1}$ (Alm et al., 1997). However, most studies report mean annual NEE in a much smaller range with multiple year averages between 20 and $60 \mathrm{~g} \mathrm{C} \mathrm{m}^{-2} \mathrm{yr}^{-1}$ (Sottocornola and Kiely, 2005; Dunn et al., 2007; Roulet et al., 2007). The NEE from minerotrophic peatlands (fens), particularly mineral poor fens, shows a similar range and interannual variability as that of bogs (Shurpali et al., 1995; Joiner et al., 1999; Aurela et al., 2001, 2007). While all these studies show large differences among years and peatland types in annual NEE the observed ranges are relatively smaller than those observed among other major ecosystem types. Humphreys et al. (2006) did a comparative analysis of NEE from seven contrasting bogs and fens and found that, despite large differences in water table depth, water chemistry, and plant community structure, that the summer daily NEE was about $1.5 \mathrm{~g} \mathrm{C} \mathrm{m}^{-2} \mathrm{yr}^{-1}$ for all peatlands. This result implies that the differences in cumulative annual NEE between individual peatlands are more a function of broad scale geographic location and physical setting rather than internal factors such as the hydrology, community structure and biogeochemistry. More long-term and continuous records of NEE for a wider range of peatland types and geographical locations are required to support the above conclusion. An analysis by Lindroth et al. (2007) for four different peatlands in Sweden and Finland shows that photosynthetic radiation (PAR) was the dominant control on the gross and net uptake of $\mathrm{CO}_{2}$. Frolking et al. (1998) found that in 
comparison with other upland ecosystems (e.g. closed forest, grasslands and croplands), one NEE-PAR relationship with smaller ecosystem respiration and NEE rates applied to the two broad groups of ombrotrophic and minerotrophic peatlands. At a landscape scale, internal factors such as moisture, temperature, vegetation composition and nutrient status all seem to play secondary roles. This may be partly due to the confounding effects that some environmental factors have on the components of NEE. A modest increase in temperature, for example, may both stimulate $\mathrm{C}$ assimilation and $\mathrm{C}$ respiration, diminishing or even cancelling out its net effect on NEE. If it is confirmed that the range of NEE among peatland types is much smaller than initially expected then it will simplify the task of modeling peatland $\mathrm{CO}_{2}$ exchange at coarse scales in global models.

3.2.2 Exchange of $\mathrm{CH}_{4}$ between peatlands and the atmosphere

There are many comprehensive reviews of $\mathrm{CH}_{4}$ flux from peatlands (Moore et al., 1998). These show that the temporal and spatial variability of $\mathrm{CH}_{4}$ exchange is much more variable, by several orders of magnitude, than that of peatland $\mathrm{CO}_{2}$-NEE. Drier bogs with persistently low water tables, with or without permafrost, have very small $\mathrm{CH}_{4}$ flux of less than $1 \mathrm{~g} \mathrm{C} \mathrm{m}^{-2} \mathrm{yr}^{-1}$ (Roulet et al., 2007; Christensen et al., 2004) while wetter bogs can have intermediate fluxes of $5-8 \mathrm{~g} \mathrm{C} \mathrm{m}^{-2} \mathrm{yr}^{-1}$ (Laine et al., 2007). In wetter fens, particularly when there is significant cover of sedges, the annual flux can exceed $15 \mathrm{~g} \mathrm{C} \mathrm{m}^{-2} \mathrm{yr}^{-1}$ (Shurpali et al., 1993; Suyker et al., 1996). In a boreal landscape, Bubier et al. (2005) estimated a regional $\mathrm{CH}_{4}$ flux of $7 \mathrm{~g} \mathrm{C} \mathrm{m}^{-2} \mathrm{yr}^{-1}$, but the fluxes from individual peatlands types differed by a factor 10 or more (see also Schrier et al., 2008). Back calculating from the recent estimates of the atmospheric burden of $\mathrm{CH}_{4}$ from high latitude wetlands $\left(8-20 \times 10^{12} \mathrm{~g} \mathrm{CH}_{4} \mathrm{yr}^{-1}\right.$, Mikaloff Fletcher et al., 2004; Chen and Prinn, 2006) yields an average emission of $2-5 \mathrm{~g} \mathrm{C} \mathrm{m}^{-2} \mathrm{yr}^{-1}$.

3.3 Putting the fluxes together: the annual $\mathrm{C}$ budget of peatlands

There are very few examples of net ecosystem $\mathrm{C}$ balances (NECB) for peatlands, where both the atmospheric fluxes of $\mathrm{CO}_{2}$ and $\mathrm{CH}_{4}$ and the water borne fluxes of DOC, POC and DIC have been measured at the same time. In this assessment of the $\mathrm{C}$ balance of a peatland it is important to be very clear on the terms. NECB requires a clear definition of terminology and we adopt in this paper the terminology discussed by Lovett et al. (2006) and Chapin et al. (2006): $\Delta_{\text {org }} \mathrm{C}$ (Lovett et al., 2006) or NECB (Chapin et al., 2006) is the accumulation of $\mathrm{C}$ in the sediments of an ecosystem after all the inputs and outputs are balanced. The NECB for northern peatlands from measurements is quite conservative ranging between 10 to $30 \mathrm{~g} \mathrm{C} \mathrm{m}^{-2} \mathrm{yr}^{-1}$. NEE is the largest term ranging between
0 and $100 \mathrm{~g} \mathrm{C} \mathrm{m}^{-2} \mathrm{yr}^{-1}$ inputs and the approximate losses via the $\mathrm{CH}_{4}$ flux and DC range respectively between 0 and 12 , and 2 and $70 \mathrm{~g} \mathrm{C} \mathrm{m}^{-2} \mathrm{yr}^{-1}$ (Fig. 4). However, the high end of the range of DC export comes from peatlands that have been disturbed or used extensively throughout part of their history for grazing and/or subjected to other forms of land-use (Worrall et al., 2003).

Examining the NECB with all its terms makes it clear that the exclusion of $\mathrm{CH}_{4}$ and DC losses could lead to an error in excess of $100 \%$. This means not only does the $\mathrm{CH}_{4}$ and DC flux need to be measured but the simulation of the response of northern peatlands to environmental changes will also need to include these loss mechanisms to make the predictions of use.

\subsection{Perturbations}

Main perturbations of peatland $\mathrm{C}$ storage and sequestration involve large-scale land-use changes, particularly for the tropical peatlands, changes in aerial nutrient input, such as $\mathrm{N}$ for the temperate peatlands (discussed in Sect. 2.2) and climate change for peatlands in the northern high latitudes. Furthermore, combined perturbations may have an additional aggravating effect, leading to higher losses than expected from each disturbance separately. For tropical peatlands, for example, the interaction between drought (brought by the Southern Oscillation), deforestation, and fire is responsible for the dramatic losses of $\mathrm{C}$ to the atmosphere. Likewise, feedbacks between permafrost melting, fire, vegetation changes and their effects on albedo may have far-reaching consequences for soil $\mathrm{C}$ stores in permafrost peatlands at the other side of the equator.

\subsubsection{Land use changes}

Currently, peatlands in many parts of the world are undergoing major transformation due to human alteration, often involving drainage and burning, particularly peat swamp forests in Southeast Asia. These peatlands store at least $42 \mathrm{Pg}$ ( 1 Petagram $=10^{15} \mathrm{~g}$ ) of soil $\mathrm{C}$ but are increasingly under threat from drainage and fires associated with plantations such as palm oil crops (Page et al., 2002) and Acacia for pulp. Hooijer et al. (2006) estimated that current $\mathrm{CO}_{2}$ emission resulting from the destruction of peatlands in Southeast Asia ( $90 \%$ emitted by Indonesia) through drainage and burning alone is equal to $8 \%$ of global fossil fuel emissions. Furthermore, the burning of peat and vegetation in Indonesia during the El Niño-Southern Oscillation (ENSO) in 1997 released an estimated $0.81-2.57 \mathrm{Pg} \mathrm{C}$, an equivalent amount of 13 to $40 \%$ of the mean annual global C emissions from fossil fuels (Page et al., 2002).

Many temperate peatlands have been drained for commercial exploitation such as agriculture, forestry or more recently windmill farming (Waldron et al., 2008). This has resulted in profound effects on peatland biogeochemistry, 

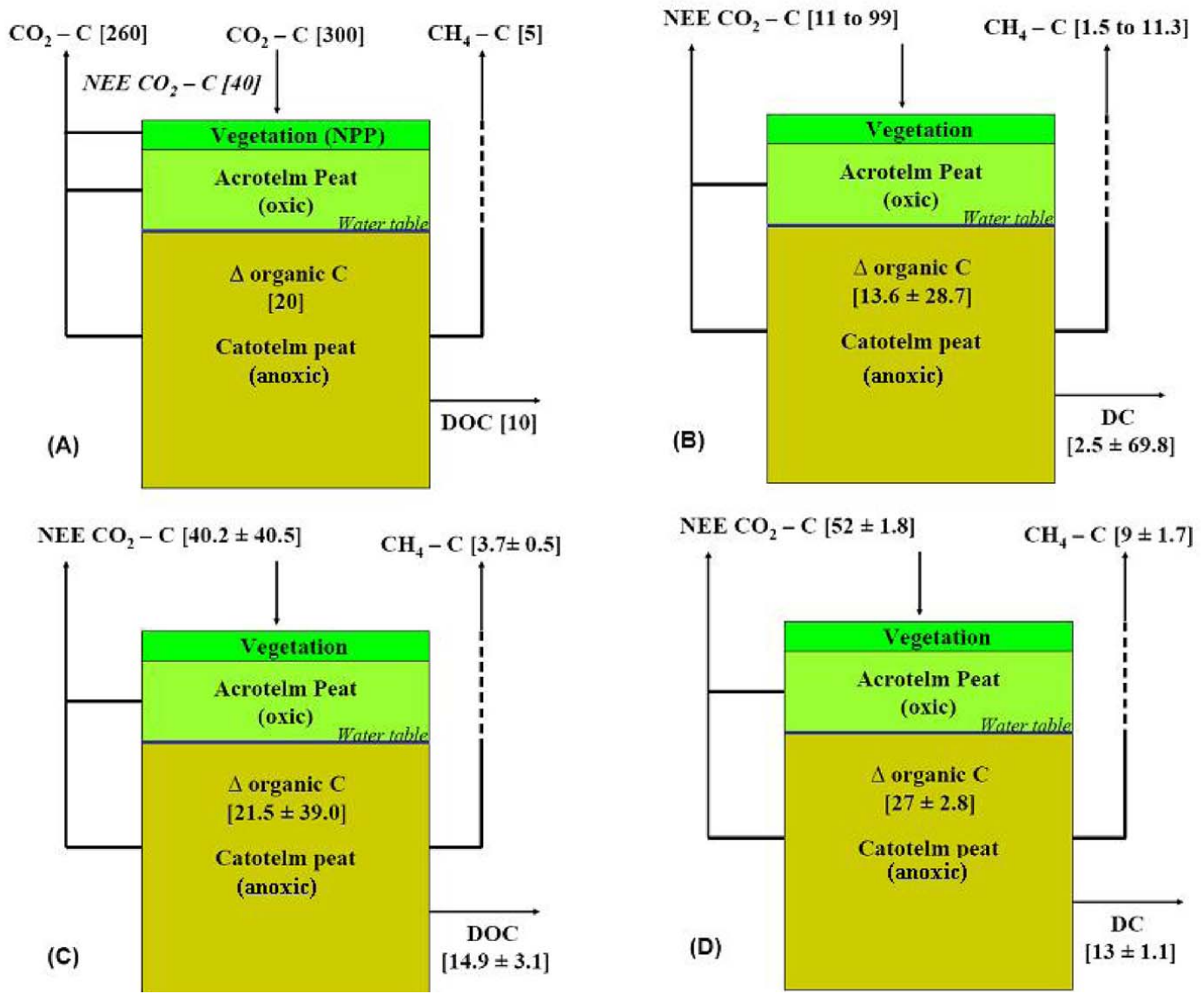

Fig. 4. Four carbon balances for northern peatlands reported in the literature. (A) Deduced C balance by Gorham (1995), (B). Average C balance of UK peatlands compiled by Worrall et al. (2003), (C) Six-year average C balance for the Mer Bleue, raised shrub bog, Southern Canada compiled from measurements of all components (Roulet et al., 2007), (D) Two-year average C balance for Degerö Stormyr, northern Sweden compiled from direct measurements of all components (Sagerfors, 2007).

vegetation and $\mathrm{C}$ loss (Strack et al., 2006). Besides the loss of peat building vegetation through the change in land use, drainage of peat soils significantly enhances POC loss through concentrated flow in the drainage channels, and increases subsurface peat erosion and soil piping, depending on time since drainage (Holden et al., 2006).

Peat extraction for energy use (Asplund, 1996) and horticultural use continues to be a major threat to the global peatland area, and may increase when fossil fuel prices raise further (Moore, 2000). Currently the largest harvesting areas are found in Russia and are estimated to be about $90000 \mathrm{~km}^{2}$ (Lappalainen, 1996).

\subsubsection{Climate change}

The increase in global temperature is felt most at the northern high latitudes, and is projected to increase further in the future (IPCC, 2007). For temperate peatlands the positive effects of increased temperature on the water table and the rate of decomposition (see chapter 2) may be locally offset by increased precipitation frequency during the growing sea- son (Moore, 2002). In contrast, some peatland regions in Southeast Asia and North America are projected to receive less precipitation resulting in lower water tables and longer dry seasons ( $\mathrm{Li}$ et al., 2007), potentially increasing wildfire frequency. For frozen peatlands in boreal regions, permafrost thawing will be the most important driver of change.

Fires release $\mathrm{C}$ into the atmosphere through the burning process and are likely to result in atmospheric and hydrological short to longer-term changes caused by decreased surface albedo, increased greenhouse gas emissions, and changes in near-surface peat properties. Additionally there is diminished net primary productivity in the aftermath of the fire that may last for about 20 years (Wieder et al., 2007). It is yet unclear at which fire cycle frequency the turning point lies where net radiative forcing turns into a net cooling effect. For boreal forest this turning point has been estimated at a fire cycle of 80 years (Randerson et al., 2006).

Temperature effects on permafrost thawing show high spatial variation as a result of a strong dominance of local controls related to vegetation composition (Camill and Clark, 
1998). The effects of permafrost thawing on peatland Caccumulation is equally uncertain. On the one hand the water released by the melting of the ice may increase water residence time (see Sect. 2.1.3), promoting peat formation and thus local $\mathrm{C}$-accumulation but increasing $\mathrm{CH}_{4}$ emission. Indeed, the $\mathrm{C}$-sequestration rate of collapse scars is among the highest reported for peatlands (Meyers-Smith et al., 2008). On the other hand, if the permafrost layer acts as a water impermeable layer, the thawing will lead to drainage, stimulating decomposition processes (see Sect. 2.1.3). In peatlands with discontinuous permafrost, severe fire events may contribute to permafrost thawing leading to more permanent vegetation changes, potentially increasing $\mathrm{C}$-accumulation in the longer term (Kuhry, 1994; Myers-Smith et al., 2008; Schuur et al., 2008).

\subsubsection{Restoration}

Many degraded peatlands are the subject of restoration projects. Management practices are varied but include raising the water table through gully and ditch blocking (Evans et al., 2005) and reseeding or planting bare surfaces (Petrone et al., 2004). These management interventions can have an immediate impact on the export of $\mathrm{C}$ to streams and rivers. Holden et al. (2007b) for example, demonstrated an almost two orders of magnitude decrease in POC export for a restoration project in northern England while Wallage et al. (2006) and Worrall et al. (2007) have shown that DOC fluxes are significantly reduced through drain blocking and water table recovery.

Quick re-vegetation of degraded peat is often possible and peat formation can be fast in gullies and drains, even without water table restoration measures, thereby still having positive effects on ecosystem C storage (Evans and Warburton, 2007). Re-vegetation outside gullies is often aimed at restoring a vascular plant cover (often Eriophorum sp.), or applying a layer of straw mulch to provide a suitable microclimate for Sphagnum mosses to re-establish (Grosvernier et al., 1995; Rochefort et al., 2003). This creates new biomass but also primes the peat through input of fresh organic matter, leading to a transient increases in peat decomposition and increased methane emission rates (Chojnicki et al., 2007), before the normal cover of mosses and shrubs develops.

\section{Peatlands and climate}

Climate change is largely driven by the accumulation of $\mathrm{C}$ in the atmosphere which is the net balance between emissions from human activities and the removal of $\mathrm{C}$ by natural sinks on land and in the ocean. Over the last 50 years, the efficiency of natural $\mathrm{CO}_{2}$ sinks has been declining (Canadell et al., 2007) and model projections show a further decline throughout the 21st century (Friedlingstein et al., 2006). High latitude and tropical peatlands have been identified as potential key vulnerabilities of the terrestrial $\mathrm{C}$ cycle likely to lead to positive feedbacks to climate change (Freeman et al., 1993; Fenner et al., 2005; Canadell et al., 2004). Global warming for the high latitude peatlands and deforestation in tropical peatlands are major drivers of the net $\mathrm{C}$ balance of these regions.

\subsection{Modelling vegetation - climate feedbacks}

Over the last eight years there has been considerable effort to couple global climate models with global $\mathrm{C}$ models to examine the magnitude and rate of potential feedbacks as a result of changes in the cycling of $\mathrm{C}$ in the terrestrial biosphere and the oceans. Until now, all the simulations agree on a positive feedback between the terrestrial biosphere, the oceans and climate. The strength of this feedback, however, varies considerably, and results range between 20 and $200 \mathrm{ppm}$ of additional atmospheric $\mathrm{CO}_{2}$ by 2100 , using the A2-IPCC emission scenario (Friedlingstein et al., 2006). Climatecarbon modelers acknowledge that there are major components, such as dynamic land-use change, $\mathrm{N}$ cycling, fire, and wetlands that can lead to large feedbacks but are currently ignored. The uncertainty in the projections caused by these omissions is considerable. Recent carbon-nitrogen-climate simulations for example show that results are dramatically different between runs that include $\mathrm{N}$ and those that do not (Thornton et al., 2007). If $\mathrm{N}$ availability is included, the capacity of the terrestrial biosphere to take up $\mathrm{C}$ and respond to changes in temperature and precipitation variations is reduced, making the carbon-climate feedback more positive. The feedback potential of wetlands is equally large. A preliminary estimate suggests that up to $100 \mathrm{Pg} \mathrm{C}$ of $\mathrm{CO}_{2}$ equivalents could be released to the atmosphere from wetlands and peatlands over the next 100 years (Gruber et al., 2004).

\subsubsection{Including peatlands in earth system models}

The inclusion of wetlands, particularly peatlands, in global models is severely constrained by the way hydrology is treated by the models, and less by the uncertainty concerning their exact location (Krankina et al., 2008). In general, they are concentrated in areas where precipitation exceeds evapotranspiration. However, the actual hydrology of wetlands that controls ecosystem structure and function is largely a function of physical setting, substrates, and topographic location at a landscape level. At present, these factors are too local to be included, and the research community is still searching for an adequate way to parameterize the issue. There have been attempts to use a topographic wetness index to simulate northern peatland distribution (Kirkby et al., 1995) and this has been extended globally by Gedney and Cox (2003). However, this approach only simulates where surface saturation occurs, whereas much of the biogeochemical processes in wetlands are a function of the seasonal water table changes over a range of 0.3-0.4 m (Moore et al., 1998). 
For peatlands the two factors that may be globally significant are the fate of the large mass of $\mathrm{C}$ stored as peat and the production and oxidation of $\mathrm{CH}_{4}$. There have been no global simulations of the fate of stored $\mathrm{C}$ but a series of local peatland models have emerged that could, in principle, with simplification be used to examine this issue at the global scale. Results from simulations using the Peatland Carbon Simulator (Frolking et al., 2001, 2002; Lafleur et al., 2003), the NUCOM-BOG model (Heijmans et al., in press) and the newly developed McGill Wetland Model (Saint Hilaire et al., 2008) show that production and decomposition in peatlands are quite sensitive to both changes in moisture and temperature.

There has been much more effort on modeling the potential feedbacks of $\mathrm{CH}_{4}$ from wetlands, including northern peatlands. Walter et al. (2001a, b) developed a process based wetland- $\mathrm{CH}_{4}$ emissions model and Shindell et al. (2004) used this model to examine the potential feedback with climate change. They simulated a $78 \%$ increase in $\mathrm{CH}_{4}$ emissions for a scenario involving a doubling of the ambient atmospheric $\mathrm{CO}_{2}$ concentration. Although most of the increase came from tropical wetlands, emissions from high latitude wetlands doubled, showing an increase from 24 to $48 \times 10^{12} \mathrm{~g} \mathrm{CH}_{4} \mathrm{yr}^{-1}$. Gedney et al. (2004) also estimated a doubling of $\mathrm{CH}_{4}$ wetland emissions from about 300 to between 500 and $600 \times 10^{12} \mathrm{~g} \mathrm{CH}_{4} \mathrm{yr}^{-1}$ by 2100 , leading to a temperature increase of 0.14 to $0.2 \mathrm{~K}$. They concluded the latter would involve a 3.5 to $5.0 \%$ increase in overall radiative forcing in comparison to the Cox et al. (2000) $\mathrm{CO}_{2}$ feedback. The latter is a factor of 2 larger than any other coupled carbon-climate simulation over the 21 st century (Friedlingstein et al., 2006).

It is too early in the global research effort to draw any conclusions about the relative strengths of the $\mathrm{CO}_{2}$ and $\mathrm{CH}_{4}$ feedback involving peatlands. Much more work is required in this area and the links among peatland surface climate, hydrology, ecosystem structure and function, and trace gas biogeochemistry represent a major challenge for the global modeling community. However, the recent modeling of the role northern peatlands over the Holocene suggest that the stored $\mathrm{C}$ in peatlands represents a present day cooling of up to $-0.5 \mathrm{~W} \mathrm{~m}^{-2}$ when both $\mathrm{CO}_{2}$ and $\mathrm{CH}_{4}$ are considered (Frolking and Roulet, 2007). Short-term decreases in the wetness of peatlands, result in a reduction of this net cooling effect, with the size of the reduction depending on whether the change is dominated by changes in net $\mathrm{CO}_{2}$ exchange (smaller) or $\mathrm{CH}_{4}$ exchange (larger) (Frolking et al., 2006).

\section{Conclusion - drivers of the $\mathrm{C}$ balance across different scales}

At a local scale the depth of the unsaturated zone together with vegetation composition are promising predictors for soil respiration through their effects on the availability of electron

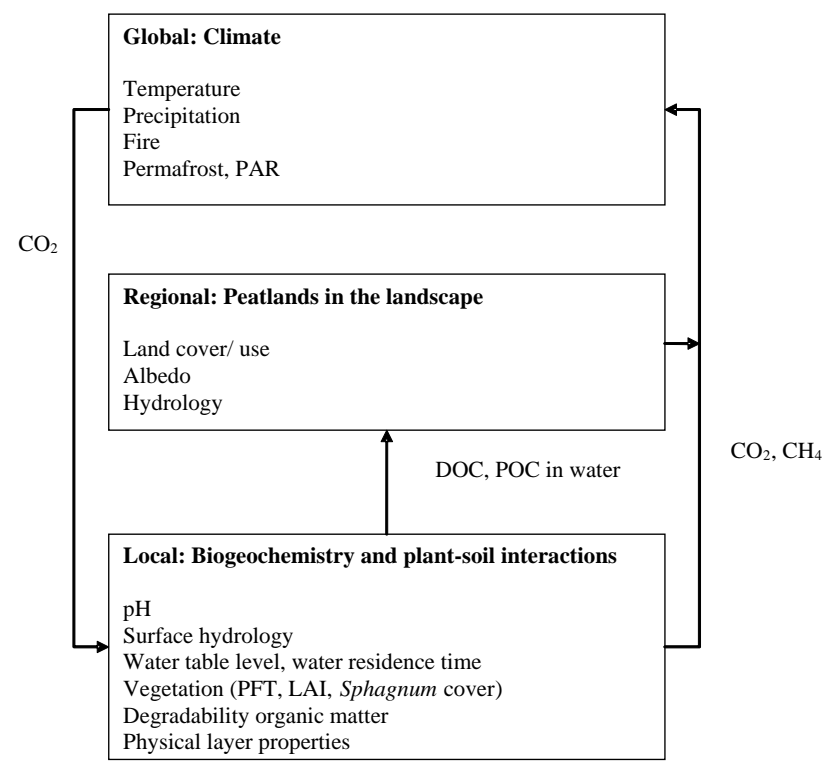

Fig. 5. Conceptual overview of the key biogeochemical and biophysical drivers of the peatland carbon balance at different spatial scales. $\mathrm{PFT}=$ Plant functional type, $\mathrm{LAI}=$ Leaf area index.

donors (organic matter) and electron acceptors (Fig. 5). At an ecosystem scale vegetation composition is in turn controlled by water level, nutrient availability and $\mathrm{pH}$. At the landscape and regional scale the percentage of peatlands (land cover), as well as their connections to other ecosystem types through subsurface and surface hydrology and topography affect $\mathrm{C}$ export to water and atmosphere. The above illustrates the scale-dependancy of the main drivers, making full integration across scales difficult. Yet, a large part of the drivers are related to some aspect of hydrology such as surface wetness, depth of the unsaturated layer, water table depth and water movement. As such, finding a way of integrating these aspects into a single parameter (perhaps by calculating water residence times) and relating it to biogeochemical processes and vegetation shifts seems one of the promising areas for future research.

Although full integration across scales is unnessary for global predictions, a more integrated knowledge of feedbacks between climate-vegetation and water dynamics across peatland types is. The relatively narrow range of observed rates of $\mathrm{C}$ accumulation in peatlands (Fig. 4) indicates the presence of such feedbacks which, over sites and years/seasons, work to reduce the high local variability in $\mathrm{C}$ accumulation rates. It also explains why the differences in cumulative annual NEE between individual peatlands are more a function of geographic location and physical setting than internal factors such as the hydrology, community structure and biogeochemistry. In order to find and quantify these feedbacks and to verify that they apply across peatland types and climatic zones, continued discussion between disciplines operating at different spatial and temporal scales is necessary. 


\subsection{Ways forward}

- Better understanding of the coupling between soil physical structure and aerobic and anaerobic respiration, with further model development at local and regional scales.

- Determining how vegetation change alters the $\mathrm{C}$ cycle and $\mathrm{C}$ mobilization in different forms (DOC, POC, gases).

- Understanding how various climate scenarios will affect the hydrology of peatlands, and how this will lead to vegetation changes and associated changes in $\mathrm{C}$ fluxes and stocks.

- Analyzing and establishing process studies in combination with ecosystem flux measurements to understand the key controls on fluxes in and out of the ecosystems (water table, temperature, etc.).

- Incorporating in biogeochemical models key processes controlling landscape $\mathrm{C}$ fluxes such as fires regimes and vegetation shifts.

- Identifying possible thresholds in $\mathrm{C}$ dynamics of peatlands to prevent large scale vulnerability of $\mathrm{C}$ stocks and associated positive feedbacks to the climate system.

- Determining a more accurate global representation of the spatial distribution of C-pools and stocks in peatlands, with particular focus on peat depth, peat bulk density and the differentiation between ombrotrophic and minerotrophic peatlands.

- Including the treatment of organic soils, and particularly peat, in the $\mathrm{C}$ cycle components of fully coupled climate models.

Acknowledgements. We are indebted to the Editors of Biogeosciences for their continuous support in putting together this special issue. We acknowledge Peatnet (www.peatnet.siu.edu) and the Global Carbon Project (www.globalcarbonproject.org) for co-sponsoring the First International Symposium on Carbon in Peatlands held in Wageningen, the Netherlands, in April 2007, and for their financial contribution to this special issue. Finally, we thank two anonymous reviewers and Tim Moore for helpful comments to improve the first draft.

Edited by: T. Laurila

\section{References}

Achtnich, C., Bak, F., and Conrad, R.: Competition for electrondonors among nitrate reducers, ferric iron reducers, sulfate reducers, and methanogens in anoxic paddy soil, Biol. Fert. Soils, 19, 65-72, 1995.

Albers, D., Migge, S., Schaefer, M., and Scheu, S.: Decomposition of beech leaves (Fagus sylvatica) and spruce needles (Picea abies) in pure and mixed stands of beech and spruce, Soil Biol. Biochem., 36, 155-164, 2004.

Alm, J., Talanov, A., Saarnio, S., Silvola, J., Ikkonen, E., Aaltonen, H., Nykanen, H., and Martikainen, P. J.: Reconstruction of the carbon balance for microsites in a boreal oligotrophic pine fen, Finland, Oecologia, 110, 423-431, 1997.

Arneth, A., Kurbatova, J., Kolle, O., Shibistova, O. B., Lloyd, J., Vygodskaya, N. N., and Schulze, E. D.: Comparative ecosystematmosphere exchange of energy and mass in a European Russian and a central Siberian bog II. Interseasonal and interannual variability of $\mathrm{CO}_{2}$ fluxes, Tellus B, 54, 514-530, 2002.

Asplund, D.: Energy use of peat, in: Peatlands in Finland, edited by: Vasander, H., Finnish Peatland Society, Helsinki, 107-113, 1996

Aurela, M., Laurila, T., and Tuovinen, J. P.: Seasonal $\mathrm{CO}_{2}$ balances of a subarctic mire, J. Geophys. Res.-Atmos., 106, 1623-1637, 2001.

Aurela, M., Riutta, T., Laurila, T., Tuovinen, J. P., Vesala, T., Tuittila, E. S., Rinne, J., Haapanala, S., and Laine, J.: $\mathrm{CO}_{2}$ exchange of a sedge fen in southern Finland - the impact of a drought period, Tellus B, 59, 826-837, 2007.

Backeus, I.: Bog vegetation re-mapped after 60 years - studies on Skagershultamossen, central Sweden, Oikos, 23, 384-393, 1972.

Baird, A. J.: Field estimation of macropore functioning and surface hydraulic conductivity in a fen peat, Hydrol. Process., 11, 287295, 1997.

Bay, R. R.: Runoff from small peatland watersheds, J. Hydrol., 9, 90-102, 1969.

Beer, J. and Blodau, C.: Transport and thermodynamics constrain belowground carbon turnover in a northern peatland, Geochim. Cosmochim. Ac., 71, 2989-3002, 2007.

Benoit, R. E. and Starkey, R. L.: Inhibition of decomposition of cellulose and some other carbohydrates by tannin, Soil Sci., 105, 291-296, 1968.

Berendse, F., Van Breemen, N., Rydin, H., Buttler, A., Heijmans, M., Hoosbeek, M. R., Lee, J. A., Mitchell, E., Saarinen, T., Vasander, H., and Wallen, B.: Raised atmospheric $\mathrm{CO}_{2}$ levels and increased $\mathrm{n}$ deposition cause shifts in plant species composition and production in Sphagnum bogs, Glob. Change Biol., 7, 591-598, 2001.

Belyea, L. R. and Baird, A. J.: Beyond the limits to peat bog growth: cross-scale feedback in peatland development, Ecol. Mon., 76, 299-322, 2006.

Billett, M. F., Deacon, C. M., Palmer, S. M., Dawson, J. J. C., and Hope, D.: Connecting organic carbon in stream water and soils in a peatland catchment, J. Geophys. Res.-Bio., 111, G02010, doi:10.1029/2005JG000065, 2006.

Blodau, C.: Carbon cycling in peatlands - a review of processes and controls, Environ. Rev., 10, 111-134, 2002.

Blodau, C., Basiliko, N., and Moore, T. R.: Carbon turnover in peatland mesocosms exposed to different water table levels, Biogeochemistry, 67, 331-351, 2004. 
Blodau, C., Roulet, N. T., Heitmann, T., Stewart, H., Beer, J., Lafleur, P., and Moore, T. R.: Belowground carbon turnover in a temperate ombrotrophic bog, Global Biogeochem. Cy., 21, GB1021, doi:10.1029/2005GB002659, 2007.

Bragazza, L., Freeman, C., Jones, T., Rydin, H., Limpens, J., Fenner, N., Ellis, T., Gerdol, R., Hajek, M., Lacumin, P., Kutnar, L., Tahvanainen, T., and Toberman, H.: Atmospheric N deposition promotes carbon loss from peat bogs, P. Natl. Acad. Sci. USA, 103, 19386-19389, 2006.

Bubier, J., Moore, T., Savage, K., and Crill, P.: A comparison of methane flux in a boreal landscape between a dry and a wet year, Global Biogeochem. Cy., 19, GB1023, doi:10.1029/2004GB002351, 2005.

Bubier, J. L., Moore, T. R., and Bledzki, L. A.: Effects of nutrient addition on vegetation and carbon cycling in an ombrotrophic bog, Glob. Change Biol., 13, 1168-1186, 2007.

Buffam, I., Laudon, H., Oquist, M., Wallin, M., Agren, A., and Bishop, K.: Spatial and temporal dynamics of fluvial C export from Swedish boreal peatlands, in: Proceedings of the 1st International Symposium on Carbon in Peatlands, Wageningen, The Netherlands, 15-18 April, 2007, p. 29, 2007.

Burke, R. M. and Cairney, J. W. G.: Laccases and other polyphenol oxidases in ecto- and ericoid mycorrhizal fungi, Mycorrhiza, 12, 105-116, 2002.

Buytaert, W., Célleri, R., De Bièvre, B., Cisneros, F., Wyseure, G., Deckers, J., and Hofstede, R.: Human impact on the hydrology of the Andean páramos, Earth-Sci. Rev., 79, 53-72, 2006.

Canadell, J. G., Ciais, P., Cox, P., and Heimann, M.: Quantifying, understanding and managing the carbon cycle in the next decades, Clim. Change, 67, 147-160, 2004.

Canadell, J. G., Le Quere, C., Raupach, M. R., Field, C. B., Buitenhuis, E. T., Ciais, P., Camill, P., and Clark, J. S.: Climate change disequilibrium of boreal permafrost peatlands caused by local processes, Am. Nat., 151, 207-222, 1998

Carey, S. K. and Woo, M-K.: The role of soil pipes as a slope runoff mechanism, Subarctic Yukon, Canada, J. Hydrol., 233, 206-222, 2000

Conway, T. J., Gillett, N. P., Houghton, R. A., and Marland, G.: Contributions to accelerating atmospheric $\mathrm{CO}_{2}$ growth from economic activity, carbon intensity, and efficiency of natural sinks, P. Natl. Acad. Sci. USA, 104, 18 866-18 870, 2007.

Chanton, J. P., Bauer, J. E., Glaser, P. A., Siegel, D. I., Kelley, C. A., Tyler, S. C., Romanowicz, E. H., and Lazrus, A.: Radiocarbon evidence for the substrates supporting methane formation within northern Minnesota peatlands, Geochim. Cosmochim. Ac., 59, 3663-3668, 1995.

Chanton, J. P. and Whiting, G. J.: Methane stable isotopic distributions as indicators of gas transport mechanisms in emergent aquatic plants, Aquat. Bot., 54, 227-236, 1996.

Chapin, F. S., Woodwell, G. M., Randerson, J. T., Rastetter, E. B., Lovett, G. M., Baldocchi, D. D., Clark, D. A., Harmon, M. E., Schimel, D. S., Valentini, R., Wirth, C., Aber, J. D., Cole, J. J., Goulden, M. L., Harden, J. W., Heimann, M., Howarth, R. W., Matson, P. A., McGuire, A. D., Melillo, J. M., Mooney, H. A., Neff, J. C., Houghton, R. A., Pace, M. L., Ryan, M. G., Running, S. W., Sala, O. E., Schlesinger, W. H., and Schulze, E. D.: Reconciling carbon-cycle concepts, terminology, and methods, Ecosystems, 9, 1041-1050, 2006.

Chapin III, F. S., Sturm, M., Serreze, M. C., McFadden, J. P., Key,
J. R., Lloyd, A. H., McGuire, A. D., Rupp, T. S., Lynch, A. H., Schimel, J. P., Beringer, J., Chapman, W. L., Epstein, H. E., Euskirchen, E. S., Hinzman, L. D., Jia, G., Ping, C.-L. Tape, K. D., Thompson, C. D. C., Walker, D. A., and Welker, J. M.: Role of land-surface changes in arctic summer warming, Science, 310, 657-660, 2005.

Chen, Y. H. and Prinn, R. G.: Estimation of atmospheric methane emissions between 1996 and 2001 using a three-dimensional global chemical transport model, J. Geophys. Res.-Atmos., 111, D10307, doi:10.1029/2005JD006058, 2006.

Chojnicki, B. H., Augustin, J., and Olejnik, J.: Impact of reflooding on greenhouse gas exchange of degraded fen peatlands, in: Proceedings of the 1st International Symposium on Carbon in Peatlands, Wageningen, The Netherlands, 15-18 April, 2007, p. 33, 2007.

Christensen, T. R., Johansson, T. R., Akerman, H. J., Mastepanov, M., Malmer, N., Friborg, T., Crill, P., and Svensson, B. H.: Thawing sub-arctic permafrost: Effects on vegetation and methane emissions, Geophys. Res. Lett., 31, L04501, doi:10.1029/2003GL018680, 2004.

Claus, H.: Laccases: Structure, reactions, distribution, Micron, 35, 93-96, 2004.

Clymo, R. S., Turunen, J., and Tolonen, K.: Carbon accumulation in peatland, Oikos, 81, 368-388, 1998.

Coles, J. R. P. and Yavitt, J. B.: Linking belowground carbon allocation to anaerobic $\mathrm{CH}_{4}$ and $\mathrm{CO}_{2}$ production in a forested peatland, New York State, Geomicrobiol. J., 21, 445-455, 2004.

Conrad, R.: Contribution of hydrogen to methane production and control of hydrogen concentrations in methanogenic soils and sediments, Fems. Microbiol. Ecol., 28, 193-202, 1999.

Cox, P. M., Betts, R. A., Jones, C. D., Spall, S. A., and Totterdell, I. J.: Acceleration of global warming due to carbon-cycle feedbacks in a coupled climate model, Nature, 408, 184-187, 2000.

Crawford, D. L.: Lignocellulose decomposition by selected Streptomyces strains, Appl. Environ. Microbiol., 35, 1041-1045, 1978.

Criquet, S., Tagger, S., Vogt, G., Iacazio, G., and Le Petit, J.: Laccase activity of forest litter, Soil Biol. Biochem., 31, 1239-1244, 1999.

Crow, S. E. and Wieder, R. K.: Sources of $\mathrm{CO}_{2}$ emission from a northern peatland: Root respiration, exudation, and decomposition, Ecology, 86, 1825-1834, 2005.

Dawson, J. J. C., Billett, M. F., Neal, C., and Hill, S.: A comparison of particulate, dissolved and gaseous carbon in two contrasting upland streams in the UK, J. Hydrol., 257, 226-246, 2002.

Dillon, P. J. and Molot, L. A.: Effect of landscape form on export of dissolved organic carbon, iron, and phosphorus from forested stream catchments, Water Resour. Res., 33, 2591-2600, 1997.

Dorrepaal, E., Cornelissen, J. H. C., Aerts, R., Wallen, B., and Van Logtestijn, R. S. P.: Are growth forms consistent predictors of leaf litter quality and decomposability across peatlands along a latitudinal gradient?, J. Ecol., 93, 817-828, 2005.

Dunn, A. L., Barford, C. C., Wofsy, S. C., Goulden, M. L., and Daube, B. C.: A long-term record of carbon exchange in a boreal black spruce forest: Means, responses to interannual variability, and decadal trends, Glob. Change Biol., 13, 577-590, 2007.

Endo, K., Hayashi, Y., Hibi, T., Hosono, K., Beppu, T., and Ueda, K.: Enzymological characterization of EpoA, a laccase-like phenol oxidase produced by Streptomyces griseus, J. Biochem., 133, 
671-677, 2003.

Evans, M. G., Allott, T. E. H., Holden, J., Flitcroft, C., and Bonn, A. (Eds.): Understanding gully blocking in deep peat, Derbyshire: Moors for the Future Report, 4, 2005.

Evans, M. G. and Warburton, J.: Geomorphology of upland peat, Blackwell, London, 2007.

Fechner-Levy, E. J. and Hemond, H. F.: Trapped methane volume and potential effects on methane ebullition in a northern peatland, Limnol. Oceanogr., 41, 1375-1383, 1996.

Fenner, N., Freeman, C., and Reynolds, B.: Hydrological effects on the diversity of phenolic degrading bacteria in a peatland: Implications for carbon cycling, Soil Biol. Biochem., 37, 1277-1287, 2005.

Fenner, N., Freeman, C., Lock, M. A., Harmens, H., Reynolds, B., and Sparks, T.: Interactions between elevated $\mathrm{CO}_{2}$ and warming could amplify DOC exports from peatland catchments, Environ. Sci. Technol., 41, 3146-3152, 2007b.

Fenner, N., Ostle, N. J., McNamara, N., Sparks, T., Harmens, H., Reynolds, B., and Freeman, C.: Elevated $\mathrm{CO}_{2}$ effects on peatland plant community carbon dynamics and DOC production, Ecosystems, 10, 635-647, 2007a.

Fraser, C. J. D., Roulet, N. T., and Lafleur, M.: Groundwater flow patterns in a large peatland, J. Hydrol., 246, 142-154, 2001.

Freeman, C., Lock, M. A., and Reynolds, B.: Fluxes of $\mathrm{CO}_{2}, \mathrm{CH}_{4}$ and $\mathrm{N}_{2} \mathrm{O}$ from a Welsh peatland following simulation of watertable draw-down - potential feedback to climatic-change, Biogeochemistry, 19, 51-60, 1993.

Freeman, C., Evans, C. D., Monteith, D. T., Reynolds, B., and Fenner, N.: Export of organic carbon from peat soils, Nature, 412, 785-785, 2001b.

Freeman, C., Ostle, N., and Kang, H.: An enzymic 'latch' on a global carbon store - a shortage of oxygen locks up carbon in peatlands by restraining a single enzyme, Nature, 409, 149-149, 2001a.

Freeman, C., Ostle, N. J., Fenner, N., and Kang, H.: A regulatory role for phenol oxidase during decomposition in peatlands, Soil Biol. Biochem., 36, 1663-1667, 2004.

Friborg, T., Soegaard, H., Christensen, T. R., Lloyd, C. R., and Panikov, N. S.: Siberian wetlands: Where a sink is a source, Geophys. Res. Lett., 30, 2129, doi:10.1029/2003GL017797, 2003.

Friedlingstein, P., Cox, P., Betts, R., Bopp, L., Von Bloh, W., Brovkin, V., Cadule, P., Doney, S., Eby, M., Fung, I., Bala, G., John, J., Jones, C., Joos, F., Kato, T., Kawamiya, M., Knorr, W., Lindsay, K., Matthews, H. D., Raddatz, T., Rayner, P., Reick, C., Roeckner, E., Schnitzler, K. G., Schnur, R., Strassmann, K., Weaver, A. J., Yoshikawa, C., and Zeng, N.: Climate-carbon cycle feedback analysis: Results from the (CMIP)-M-4 model intercomparison, J. Climate, 19, 3337-3353, 2006.

Frolking, S. E., Bubier, J. L., Moore, T. R., Ball, T., Bellisario, L. M., Bhardwaj, A., Carroll, P., Crill, P. M., Lafleur, P. M., McCaughey, J. H., Roulet, N. T., Suyker, A. E., Verma, S. B., Waddington, J. M., and Whiting, G. J.: Relationship between ecosystem productivity and photosynthetically active radiation for northern peatlands, Global Biogeochem. Cy., 12, 115-126, 1998.

Frolking, S., Roulet, N. T., Moore, T. R., Richard, P. J. H., Lavoie, M., and Muller, S. D.: Modeling northern peatland decomposition and peat accumulation, Ecosystems, 4, 479-498, 2001.

Frolking, S., Roulet, N. T., Moore, T. R., Lafleur, P. M., Bubier, J.
L., and Crill, P. M.: Modeling seasonal to annual carbon balance of Mer Bleue bog, Ontario, Canada, Global Biogeochem. Cy., 16, 1030, doi:10.1029/2001GB001457, 2002.

Frolking, S., Roulet, N., and Fuglestvedt, J.: How northern peatlands influence the earth's radiative budget: Sustained methane emission versus sustained carbon sequestration, J. Geophys. Res.-Bio., 111, G01008, doi:10.1029/2005JG000091, 2006.

Frolking, S. and Roulet, N. T.: Holocene radiative forcing impact of northern peatland carbon accumulation and methane emissions, Glob. Change Biol., 13, 1079-1088, 2007.

Gauci, V., Dise, N., and Fowler, D.: Controls on suppression of methane flux from a peat bog subjected to simulated acid rain sulfate deposition, Global Biogeochem. Cy., 16, 1004, doi:10.1029/2000GB001370, 2002.

Gedney, N. and Cox, P. M.: The sensitivity of global climate model simulations to the representation of soil moisture heterogeneity, J. Hydrometeorol., 4, 1265-1275, 2003.

Gedney, N., Cox, P. M., and Huntingford, C.: Climate feedback from wetland methane emissions, Geophys. Res. Lett., 31, L20503, doi:10.1029/2004GL020919, 2004.

Gibson, J. J., Edwards, T. W. D., and Prowse, T. D.: Runoff generation in a high borealwetland in northern Canada, Nordic Hydrol., 24, 213-224, 1993.

Gorham, E.: The biogeochemistry of northern peatlands and its possible responses to global warming, in: Biotic feedbacks in the global climate system: Will the warming feed the warming?, edited by: Woodwell, G. M. and Mackenzie, F. T., Oxford University Press, New York, USA, 169-187, 1995.

Grosvernier, P., Matthey, Y., and Buttler, A.: Microclimate and physical properties of peat: new clues to the understanding of bog restoration processes, in: Restoration of temperate wetlands, edited by: Wheeler, B. D., Shaw, S. C., Foijt, W. J., and Robertson R. A., John Wiley \& Sons Ltd., Chichester, UK, 435-450, 1995.

Gruber, N., Friedlingstein, P., Field, C. B., Valentini, R., Heimann, M., Richey, J. E., Romero-Lankao, P., Schulze, D., and Chen, C. T. A.: The vulnerability of the carbon cycle in the 21 st century: An assessment of carbon-climate-human interactions, in: The global carbon cycle: Integrating humans, climate, and the natural world, edited by: Field, C. B. and Raupach, M. R., Island Press, Washington, DC, USA, 45-76, 2004.

Gunnarsson, U., Rydin, H., and Sjors, H.: Diversity and pH changes after 50 years on the boreal mire Skattlosbergs Stormosse, central Sweden, J. Veg. Sci., 11, 277-286, 2000.

Gunnarsson, U., Malmer, N., and Rydin, H.: Dynamics or constancy in Sphagnum dominated mire ecosystems? A 40-year study, Ecography, 25, 685-704, 2002.

Gunnarsson, U. and Flodin, L. A.: Vegetation shifts towards wetter site conditions on oceanic ombrotrophic bogs in southwestern Sweden, J. Veg. Sci., 18, 595-604, 2007.

Hammel, K. E.: Fungal degradation of lignin, in: Driven by nature: Plant litter quality and decomposition, edited by: Cadish, G. and Giller, K. E., CAB International, 33-45, 1997.

Heijmans, M. M. P. D., Klees, H., de Visser, W., and Berendse, F.: Response of a Sphagnum bog plant community to elevated $\mathrm{CO}_{2}$ and N supply, Plant Ecol., 162, 123-134, 2002.

Heijmans, M. M. P. D., Mauquoy, D., vanGeel, B., and Berendse, F.: Long-term effects of climate change on vegetation and carbon dynamics in peat bogs, J. Veg. Sci., 19, 307-320, 2008. 
Heitmann, T., Goldhammer, T., Beer, J., and Blodau, C.: Electron transfer processes of dissolved organic matter and their potential significance for anaerobic respiration in a northern bog, Glob. Change Biol., 13, 1771-1785, 2007

Holden, J., Burt, T. P., and Cox, N. J.: Macroporosity and infiltration in blanket peat: The implications of tension disc infiltrometer measurements, Hydrol. Process., 15, 289-303, 2001.

Holden, J. and Burt, T. P.: Hydraulic conductivity in upland blanket peat: Measurement and variability, Hydrol. Process., 17, 12271237, 2003b.

Holden, J. and Burt, T. P.: Runoff production in blanket peat covered catchments, Water Resour. Res., 39, 1191, doi:10.1029/2003WR002067, 2003a.

Holden, J., Evans, M. G., Burt, T. P., and Horton, M.: Impact of land drainage on peatland hydrology, J. Environ. Qual., 35, 1764-1778, 2006.

Holden, J., Shotbolt, L., Bonn, A., Burt, T. P., Chapman, P. J., Dougill, A. J., Fraser, E. D. G., Hubacek, K., Irvine, B., Kirkby, M. J., Reed, M. S., Prell, C., Stagl, S., Stringer, L. C., Turner, A., and Worrall, F.: Environmental change in moorland landscapes, Earth-Sci. Rev., 82, 75-100, 2007a.

Holden, J., Gascoign, M., and Bosanko, N. R.: Erosion and natural revegetation associated with surface land drains in upland peatlands, Earth Surf. Proc. Land., 32, 1547-1557, $2007 \mathrm{~b}$.

Hooijer, A., Silvius, M., Woesten, H., and Page, S.: Peat- $\mathrm{CO}_{2}$ : Assessment of $\mathrm{CO}_{2}$ emissions from drained peatlands in SE Asia, Delft Hydraulics report Q3943, 41 pp., 2006.

Hornibrook, E. R. C., Bowes, H. L., Culbert, A., and Gallego-Sala, A. V.: Methanotrophy potential versus methane supply by pore water diffusion in peatlands, Biogeosciences Discuss., 5, 26072643, 2008,

http://www.biogeosciences-discuss.net/5/2607/2008/.

Hullo, M. F., Moszer, I., Danchin, A., and Martin-Verstraete, I.: CotA of Bacillus subtilis is a copper-dependent laccase, J. Bacteriol., 183, 5426-5430, 2001.

Humphreys, E. R., Lafleur, P. M., Flanagan, L. B., Hedstrom, N., Syed, K. H., Glenn, A. J., and Granger, R.: Summer carbon dioxide and water vapor fluxes across a range of northern peatlands, $\mathrm{J}$. Geophys. Res.-Bio., 111, G04011, doi:10.1029/2005JG000111, 2006.

IPCC: Climate change, 2007: The physical science basis, Contribution of working group I to the fourth assessment report of the intergovernmental panel on climate change, edited by: Solomon, S., Qin, D., Manning, M., Chen, Z., Marquis, M., Averyt, K. B., Tignor, M., and Miller, H. L., Cambridge University Press, Cambridge, UK and New York, USA, 996 pp., http://www.ipcc.ch/ipccreports/ar4-wg1.htm, 2007.

Jauhiainen, J., Vasander, H., and Silvola, J.: Nutrient concentration in Sphagna at increased N-deposition rates and raised atmospheric $\mathrm{CO}_{2}$ concentrations, Plant Ecol., 138, 149-160, 1998.

Joiner, D. W., Lafleur, P. M., McCaughey, J. H., and Bartlett, P. A.: Interannual variability in carbon dioxide exchanges at a boreal wetland in the BOREAS northern study area, J. Geophys. Res.Atmos., 104, 27 663-27 672, 1999.

Joosten, H.: The IMCG Global Peatland Database, www.imcg.net/ gpd/gpd.htm, 2004.

Keller, J. K. and Bridgham, S. D.: Pathways of anaerobic carbon cycling across an ombrotrophic-minerotrophic peatland gradient, Limnol. Oceanogr., 52, 96-107, 2007.
Kirkby, M. J., Kneale, P. E., Lewis, S. L., and Smith, R. T.: Modelling the form and distribution of peat mires, in: Hydrology and hydrochemistry of British wetlands, edited by: Heathwaite, J. M. R. and Heathwaite, A. L., John Wiley, New York, USA, 83-93, 1995.

Knorr, K.-H., Glaser, B., and Blodau, C.: Fluxes and ${ }^{13} \mathrm{C}$ isotopic composition of dissolved carbon and pathways of methanogenesis in a fen soil exposed to experimental drought, Biogeosciences, 5, 1457-1473, 2008, http://www.biogeosciences.net/5/1457/2008/.

Krankina, O. N., Pflugmacher, D., Friedl, M., Cohen, W. B., Nelson, P., a nd Baccini, A.: Meeting the challenge of mapping peatlands with remotely sensed data, Biogeosciences Discuss., 5, 2075-2101, 2008, http://www.biogeosciences-discuss.net/5/2075/2008/.

Kristjansson, J. K., Schonheit, P., and Thauer, R. K.: Different Ks-values for hydrogen of methanogenic bacteria and sulfate reducing bacteria - an explanation for the apparent inhibition of methanogenesis by sulfate, Arch. Microbiol., 131, 278-282, 1982.

Kuhry, P.: The role of fire in the development of Sphagnumdominated peatlands in western boreal Canada, J. Ecol., 82, 899910, 1994.

Lafleur, P. M., Roulet, N. T., Bubier, J. L., Frolking, S., and Moore, T. R.: Interannual variability in the peatland-atmosphere carbon dioxide exchange at an ombrotrophic bog, Global Biogeochem. Cy., 17, 1036, doi:10.1029/2002GB001983, 2003.

Laine, A., Wilson, D., Kiely, G., and Byrne, K. A.: Methane flux dynamics in an Irish lowland blanket bog, Plant Soil, 299, 181193, 2007.

Lappalainen, E.: Global peat resources, International Peat Society, Jyskä, Finland, 1996.

Li, W. H., Dickinson, R. E., Fu, R., Niu, G. Y., Yang, Z. L., and Canadell, J. G.: Future precipitation changes and their implications for tropical peatlands, Geophys. Res. Lett., 34, L01403, doi:10.1029/2006GL028364, 2007.

Limpens, J. and Berendse, F.: How litter quality affects mass loss and N loss from decomposing Sphagnum, Oikos, 103, 537-547, 2003.

Limpens, J., Berendse, F., and Klees, H.: How phosphorus availability affects the impact of nitrogen deposition on Sphagnum and vascular plants in bogs, Ecosystems, 7, 793-804, 2004.

Limpens, J., Heijmans, M. M. P. D., and Berendse, F.: Nitrogen in peatlands, in: Boreal peatland ecosystems, edited by: Wieder, R. K. and Vitt, D. H., Ecological Studies Series, Springer Verlag, Berlin, 195-230, 2006.

Lindroth, A., Lund, M., Nilsson, M., Aurela, M., Christensen, T. R., Laurila, T., Rinne, J., Riutta, T., Sagerfors, J., Strom, L., Tuovinen, J. P., and Vesala, T.: Environmental controls on the $\mathrm{CO}_{2}$ exchange in north European mires, Tellus B, 59, 812-825, 2007.

Lovett, G., Cole, J., and Pace, M.: Is net ecosystem production equal to ecosystem carbon accumulation?, Ecosystems, 9, 152155, 2006.

McLatchey, G. P. and Reddy, K. R.: Regulation of organic matter decomposition and nutrient release in a wetland soil, J. Environ. Qual., 27, 1268-1274, 1998.

Myers-Smith, I. H., Harden, J. W., Wilmking, M., Fuller, C. C., McGuire, A. D., and Chapin III, F. S.: Wetland succession in a permafrost collapse: interactions between fire and thermokarst, 
Biogeosciences, 5, 1273-1286, 2008,

http://www.biogeosciences.net/5/1273/2008/.

Mikaloff Fletcher, S. E., Tans, P. P., Bruhwiler, L. M., Miller, J. B., and Heimann, M.: $\mathrm{CH}_{4}$ sources estimated from atmospheric observations of $\mathrm{CH}_{4}$ and its $\mathrm{C}-13 / \mathrm{C}-12$ isotopic ratios: 2 . Inverse modeling of $\mathrm{CH}_{4}$ fluxes from geographical regions, Global Biogeochem. Cy., 18, GB4005, doi:10.1029/2004GB002224, 2004.

Mitchell, E. A. D., Buttler, A., Grosvernier, P., Rydin, H., Siegenthaler, A., and Gobat, J. M.: Contrasted effects of increased N and $\mathrm{CO}_{2}$ supply on two keystone species in peatland restoration and implications for global change, J. Ecol., 90, 529-533, 2002.

Moore, T. R., Roulet, N. T., and Waddington, J. M.: Uncertainty in predicting the effect of climatic change on the carbon cycling of Canadian peatlands, Climatic Change, 40, 229-245, 1998.

Moore, P. D.: The future of cool temperate bogs, Environ. Conserv., 29, 3-20, 2002

Moore, T. R., Bubier, J. L., Frolking, S. E., Lafleur, P. M., and Roulet, N. T.: Plant biomass and production and $\mathrm{CO}_{2}$ exchange in an ombrotrophic bog, J. Ecol., 90, 25-36, 2002.

Nedwell, D. B. and Watson, A.: $\mathrm{CH}_{4}$ production, oxidation and emission in a UK ombrotrophic peat bog - influence of SO42from acid-rain, Soil Biol. Biochem., 27, 893-903, 1995.

Neff, J. C. and Hooper, D. U.: Vegetation and climate controls on potential $\mathrm{CO}_{2}$, DOC and DON production in northern latitude soils, Glob. Change Biol., 8, 872-884, 2002.

Nilsson, M., Mikkela, C., Sundh, I., Granberg, G., Svensson, B. H., and Ranneby, B.: Methane emission from Swedish mires: National and regional budgets and dependence on mire vegetation, J. Geophys. Res.-Atmos., 106, 20 847-20 860, 2001.

Page, S. E., Siegert, F., Rieley, J. O., Boehm, H. D. V., Jaya, A., and Limin, S.: The amount of carbon released from peat and forest fires in Indonesia during 1997, Nature, 420, 61-65, 2002.

Päivänen, J.: Main physical properties of peat soils, in: Peatlands and their utilization in Finland, edited by: Laine, J., Finnish Peatland Society, Helsinki, 33-36, 1982.

Pastor, J., Solin, J., Bridgham, S. D., Updegraff, K., Harth, C., Weishampel, P., and Dewey, B.: Global warming and the export of dissolved organic carbon from boreal peatlands, Oikos, 100, 380-386, 2003.

Petrone, R. M., Price, J. S., Waddington, J. M., and von Waldow, H.: Surface moisture and energy exchange from a restored peatland, Quebec, Canada, J. Hydrol., 295, 198-210, 2004.

Pind, A., Freeman, C., and Lock, M. A.: Enzymatic degradation of phenolic materials in peatlands - measurement of phenol oxidase activity, Plant Soil, 159, 227-231, 1994.

Price, J. S.: Blanket bog in Newfoundland. 2. Hydrological processes, J. Hydrol., 135, 103-119, 1992.

Randerson, J. T., Liu, H., Flanner, M. G., Chambers, S. D., Jin, Y., Hess, P. G., Pfister, G., Mack, M. C., Treseder, K. K., Welp, L. R., Chapin, F. S., Harden, J. W., Goulden, M. L., Lyons, E., Neff, J. C., Schuur, A. E. G., and Zender, C. S.: The impact of boreal forest fire on climate warming, Science, 314, 1130-1132, 2006.

Rapson, G. L., Sykes, M. T., Lee, W. G., Hewitt, A. G., Agnew, A. D. Q., and Wilson, J. B.: Subalpine gully-head ribbon fens of the Lammerflaw and Lammermoor Ranges, Otago, New Zealand, New Zealand J. Bot., 44, 351-375, 2006.

Robroek, B. J. M., Limpens, J., Breeuwer, A., and Schouten, M. G. C.: Effects of water level and temperature on performance of four Sphagnum mosses, Plant Ecol., 190, 97-107, 2007.
Robroek, B. J. M., Schouten, M. G. C., Limpens, J., Berendse, F., and Poorter, H.: Interactive effects of water table and precipitation on net $\mathrm{CO}_{2}$ assimilation of three co-occurring Sphagnum mosses differing in distribution above the water table, Glob. Change Biol., in press, 2008.

Roulet, N. T., Lafleur, P. M., Richard, P. J. H., Moore, T. R., Humphreys, E. R., and Bubier, J.: Contemporary carbon balance and late holocene carbon accumulation in a northern peatland, Glob. Change Biol., 13, 397-411, 2007.

Rycroft, D. W., Williams, D. J. A., and Ingram, H. A. P.: Transmission of water through peat. 1. Review, J. Ecol., 63, 535-556, 1975.

Rochefort, L., Quinty, F., Campeau, S., Johnson, K., and Malterer, T. J.: North American approach to the restoration of Sphagnum dominated peatlands, Wetlands Ecol. Managem., 11, 3-20, 2003.

Rydin, H. and Barber, K. E.: Long-term and fine-scale coexistence of closely related species, Folia Geobotanica, 36, 53-61, 2001.

Rydin, H., Gunnarsson, U., and Sundberg, S.: The role of Sphagnum in peatland development and persistence, in: Boreal peatland ecosystems, edited by: Wieder, R. K. and Vitt, D. H., Ecological Studies Series, Springer Verlag, Berlin, 47-65, 2006.

Rydin, H. and Jeglum, J. K.: The biology of peatlands, Oxford University Press, Oxford, 360 pp., 2006.

Rydin, H.: Population and community ecology of bryophytes, in: Bryophyte biology, 2nd Ed., edited by: Goffinet, B. and Shaw, A. J., Cambridge University Press, Cambridge, 393-444, 2009.

Sagerfors, J.: Land-atmosphere exchange of $\mathrm{CO}_{2}$, water and energy at a boreal minerotrophic mire, Ph.D. thesis, Swedish University of Agricultural Sciences, Umea, Sweden, 70 pp., 2007.

Schaepman-Strub, G., Limpens, J., Menken, M., Bartholomeus, H. M., and Schaepman, M. E.: Towards spatial assessment of carbon sequestration in peatlands: spectroscopy based estimation of fractional cover of three plant functional types, Biogeosciences Discuss., 5, 1293-1317, 2008, http://www.biogeosciences-discuss.net/5/1293/2008/.

Schiff, S., Aravena, R., Mewhinney, E., Elgood, R., Warner, B., Dillon, P., and Trumbore, S.: Precambrian shield wetlands: Hydrologic control of the sources and export of dissolved organic matter, Climatic Change, 40, 167-188, 1998.

Schrier-Uijl, A. P., Veenendaal, E. M., Leffelaar, P. A., van Huissteden, J. C., and Berendse, F.: Spatial and temporal variation of methane emissions in drained eutrophic peat agro-ecosystems: drainage ditches as emission hotspots, Biogeosciences Discuss., 5, 1237-1261, 2008, http://www.biogeosciences-discuss.net/5/1237/2008/.

Schuur, E. A. G., Bockheim, J., Canadell, J. G., Euskirchen, E., Field, C. B., Goryachkin, S. V., Hagemann, S., Kuhry, P., Lafleur, P., Lee, H., Mazhitova, G., Nelson, F. E., Rinke, A., Romanovsky, V., Shiklomanov, N., Tarnocai, C., Venevsky, S., Vogel, J. G., and Zimov, S. A.: Vulnerability of permafrost carbon to climate change: implications for the global carbon cycle, BioSciences, 58, 701-714, 2008.

Shannon, R. D. and White, J. R.: 3-year study of controls on methane emissions from 2 Michigan peatlands, Biogeochemistry, 27, 35-60, 1994.

Shindell, D. T., Walter, B. P., and Faluvegi, G.: Impacts of climate change on methane emissions from wetlands, Geophy. Res. Lett., 31, L21202, doi:10.1029/2004GL021009, 2004.

Shurpali, N. J., Verma, S. B., Clement, R. J., and Billesbach, D. 
P.: Seasonal distribution of methane flux in a Minnesota peatland measured by eddy-correlation, J. Geophys. Res.-Atmos., 98, 20 649-20 655, 1993.

Shurpali, N. J., Verma, S. B., Kim, J., and Arkebauer, T. J.: Carbondioxide exchange in a peatland ecosystem, J. Geophys. Res.Atmos., 100, 14319-14326, 1995.

Sonnentag, O., Chen, J. M., Roberts, D. A., Talbot, J., Halligan, K. Q., and Govind, A.: Mapping tree and shrub leaf area indices in an ombrotrophic peatland through multiple endmember spectral unmixing, Remote Sens. Environ., 109, 342-360, 2007.

Sottocornola, M. and Kiely, G.: An Atlantic blanket bog is a modest $\mathrm{CO}_{2}$ sink, Geophys. Res. Lett., 32, L23804, doi:10.1029/2005GL024731, 2005.

St-Hilaire, F., Wu, J., Roulet, N. T., Frolking, S., Lafleur, P. M., Humphreys, E. R., and Arora, V.: McGill Wetland Model: evaluation of a peatland carbon simulator developed for global assessments, Biogeosciences Discuss., 5, 1689-1725, 2008, http://www.biogeosciences-discuss.net/5/1689/2008/.

Strack, M., Waddington, J. M., Rochefort, L., and Tuittila, E. S.: Response of vegetation and net ecosystem carbon dioxide exchange at different peatland microforms following water table drawdown, J. Geophys. Res.-Bio., 111, G02006, doi:10.1029/2005JG000145, 2006.

Suyker, A. E., Verma, S. B., Clement, R. J., and Billesbach, D. P.: Methane flux in a boreal fen: Season-long measurement by eddy correlation, J. Geophys. Res.-Atmos., 101, 28 637-28 647, 1996.

Thomas, K. L., Benstead, J., Davies, K. L., and Lloyd, D.: Role of wetland plants in the diurnal control of $\mathrm{CH}_{4}$ and $\mathrm{CO}_{2}$ fluxes in peat, Soil Biol. Biochem., 28, 17-23, 1996.

Thornton, P. E., Lamarque, J. F., Rosenbloom, N. A., and Mahowald, N. M.: Influence of carbon-nitrogen cycle coupling on land model response to $\mathrm{CO}_{2}$ fertilization and climate variability, Global Biogeochem. Cy., 21, GB4018, doi:10.1029/2006GB002868, 2007.

Turunen, J., Tomppo, E., Tolonen, K., and Reinikainen, A.: Estimating carbon accumulation rates of undrained mires in Finland - application to boreal and subarctic regions, Holocene, 12, 6980, 2002.

Vile, M. A., Bridgham, S. D., Wieder, R. K., and Novak, M.: Atmospheric sulfur deposition alters pathways of gaseous carbon production in peatlands, Global Biogeochem. Cy., 17, 1058, doi:10.1029/2002GB001966, 2003.

Vygodskaya, N. N., Groisman, P. Ya., Tchebakova, N. M., Kurbatova, J. A., Panfyorov, O., Parfenova, E. I., and Sogachev, A. F.: Ecosystems and climate interactions in the boreal zone of northern Eurasia, Environ. Res. Lett., 2, 45033, doi:10.1088/17489326/2/4/045033, 2007

Waddington, J. M. and Roulet, N. T.: Groundwater flow and dissolved carbon movement in a boreal peatland, J. Hydrol., 191, 122-138, 1997.
Waldron, S., Flowers, H., Arlaud, C., Bryant, C., and McFarlane, S.: The significance of organic carbon and nutrient export from peatland-dominated landscapes subject to disturbance, Biogeosciences Discuss., 5, 1139-1174, 2008,

http://www.biogeosciences-discuss.net/5/1139/2008/.

Wallage, Z. E., Holden, J., and McDonald, A. T.: Drain blocking is an effective treatment for reducing dissolved organic carbon loss and water colour in peatlands, Sci. Total Environ., 367, 811-821, 2006.

Walter, B. P., Heimann, M., and Matthews, E.: Modeling modern methane emissions from natural wetlands 1 . Model description and results, J. Geophys. Res.-Atmos., 106, 34 189-34 206, 2001a.

Walter, B. P., Heimann, M., and Matthews, E.: Modeling modern methane emissions from natural wetlands 2 . Interannual variations 1982-1993, J. Geophys. Res.-Atmos., 106, 34 207-34 219, $2001 b$.

Weltzin, J. F., Harth, C., Bridgham, S. D., Pastor, J., and Vonderharr, M.: Production and microtopography of bog bryophytes: Response to warming and water-table manipulations, Oecologia, 128, 557-565, 2001.

Weltzin, J. F., Loik, M. E., Schwinning, S., Williams, D. G., Fay, P. A., Haddad, B. M., Harte, J., Huxman, T. E., Knapp, A. K., Lin, G., Pockman, W. T., and Rebecca, M.: Assessing the Response of terrestrial ecosystems to potential changes in precipitation, Bioscience, 53, 941-952, 2003.

Wieder, R. K., Canadell, J., Limpens, J., Moore, T., Roulet, N., and Schaepman-Strub, G.: Peatlands and the carbon cycle: From local processes to global implications, EOS, 88, p. 295, 2007.

Wieder, R. K., Scott, K. D., Vile, M. A., Kamminga, K., and Vitt, D. H.: Burning bogs and changing climate: Will peatland carbon sinks become sources?, First International Symposium on Carbon in Peatlands, 15-18 April, 2007, Wageningen, The Netherlands, Wageningen, NL, p. 41, 2007.

Wiedermann, M. M., Nordin, A., Gunnarsson, U., Nilsson, M. B., and Ericson, L.: Global change shifts vegetation and plantparasite interactions in a boreal mire, Ecology, 88, 454-464, 2007.

Worrall, F., Reed, M., Warburton, J., and Burt, T.: Carbon budget for a British upland peat catchment, Sci. Total Environ., 312, 133-146, 2003.

Worrall, F., Armstrong, A., and Holden, J.: Short-term impact of peat drain-blocking on water colour, dissolved organic carbon concentration, and water table depth, J. Hydrol., 337, 315-325, 2007. 